\title{
DAY OF THE WEEK DAN MONDAY EFECT: FENOMENA YANG TERBUKTIKAN TIDAK KONSSTEN DI PASAR MODAL INDONESIA
}

\author{
Sumiyana ${ }^{1}$ \\ Universitas Gadjah Mada
}

\begin{abstract}
This research critiques Sumiyana (2007a) that is actually weak methodological research design. Sumiyana (2007a) investigates trading and nontrading periods retum only, or it doesn't split intra-day retum into short interval period. Although Sumiyana (2007a) found strongly the phenomenon of the Monday effect, but it could not capture the inside occurrence in the intra-trading periods. This study examines the day of the week and Monday effect phenomena in the Indonesian Stock Exchange using intraday data in every 30 minutes interval. Samples of the data are the firms listed in LQ 45. Sequentially, samples are filtered to stocks that actively traded in the Indonesian Stock Exchange based on trading frequency in observation period from January to December 2006. This study uses regression analysis with multiple dummies constructed by separating trading periods in every day into 12 retum periods. This research finds that day of the week phenomena occur consistently in Indonesian Stock Exchange, but the occurrence are not evenly in the same day. In addition, this study concludes that Monday effect exists partially and incidentally only.
\end{abstract}

Keywords: day of the week, Monday effect, intraday data, 30 minutes interval

\section{PENDAHULUAN}

Penelitian ini mengkritisi terhadap metodologi penelitian yang dilakukan Sumiyana (2007a) dan Cahyaningdyah (2004) yang menemukan bukti terjadinya anomali day of the week ataupun Monday effect di Bursa Efek Indonesia. Kritik berfokus pada penggunaan metode pengujian yang membasiskan pada retum sesi perdagangan dan nonperdagangan secara keseluruhan dalam hari. Pengujian yang membasiskan data retum secara keselunuhan dalam hari tidak ma mpu mendeteksi

\footnotetext{
${ }^{1}$ Ucapan terima kasih penulis berikan kepada yang telah berkonstribusi pada penelitian ini: J ogiyanto Hartono, Suwardjono, Samsubar Saleh, Sla met Sugin, Eko Suwardi, Setiyono Miharjo, Irfan Nursa smito, Andreas Budi Pumomo, Ertambang Nahartyo, Sony Warsono, \& Nofie Iman (UGM, Jogyakarta), I Made Narsa, Ardianto, \& Rahmat Setyawan (Unair, Surabaya), Rahmat Febrianto (Andalas, Padang), Sri Suryaningsum, \& Zuhrotun (UPN Jogyakarta), Dody Hapsara, \& Efraim Fredinand Gin (STIE YKPN, J ogyakarta), Abdullah Taman, Dennies Suprantinah, \& Ratna Candrasari (UNY J ogyakarta), Dwi Ratmo no (Sugiyopranoto, Semarang), Yavida Nurima (J anabadra, Jogyakarta), Muha mmad Sya fiq (STIE Indonesia, Jakarta). Kritik, komentar dan koreksi yang membangun dapat dihubungkan langsung ke sumiyana@fe.ugm.ac.id a tau (0274)7842513.
} 
secara valid terhadap kejadian nil pergerakan harga saham, khususnya day of the week ataupun Monday effect.

Sumiyana (2007a) membuktikan bahwa keberadaan Monday effect secara ril a da yang disebabkan oleh adanya rata-rata retum negatif yang eksesif dari penutupan Jum'at sampai dengan penutupan Senin (nontrading weekend effect). Retum periode nonperdagangan istirahat malam pada hari Senin menunjukkan adanya perbedaan yang signifikan secara statistis dalam bandingannya dengan retum periode malam pada hari-hari yang la innya. Terbukti valid bahwa perbedaan yang signifikan secara statistis secara total. Retum negatif yang eksesif pada periode malam mengindikasikan pengaruh periode nonperdagangan akhir minggu. Demikian juga, retum perio de perdagangan dan nonperdagangan pada hari Senin untuk sesi pertama, sesi istirahat siang, dan sesi kedua menunjukkan perbedaan yang signifikan secara statistis dalam bandingannya dengan sesi-sesi yang sesuai pada hari-hari yang la innya.

Cahyaningdyah (2004) menguji fenomena day of the week dan terbukti terjadi di Bursa Efek Indonesia. Berdasarkan penelitian yang dilakukan oleh selama periode Januari 2001 sampai dengan Desember 2003 menunjukkan adanya kesamaan dengan pola retum saham harian di bursa efek US yang menunjukkan bukti bahwa rata-rata retum terrendah terjadi pada hari Senin (Monday effect) dan rata-rata retum tertinggi tejadi pada hari perdagangan Jum'at (weekend effect). Hasil penelitian ini menyajikan bukti empirs tentang pengaruh hari perdagangan terhadap retum saham di Bursa Efek Indonesia.

Penelitian-penelitian terda hulu menunjukkan adanya retum negatif untuk hari Senin dan retum positif terjadi selama pertengahan minggu. Oleh karena itu, anomali ini dikenal dengan Monday effect. Penelitian pertama yang mendokumentasikan tentang Monday effect pada tahun 1931 (Maberly 1995). Perhatian terhadap fenomena ini meningkat setelah Cross (1973) dan French (1980) mengemukakan adanya retum saham yang tidak nomal sepanjang akhir minggu. Sejumlah penelitian kemudian muncul untuk memperkuat fenomena Monday effect yang menggunakan berbagai peniode waktu dan berbagai indeks retum saham yang yang berbeda. Anomali ini tidak hanya terjadi di pasar modal Amerika, tetapi juga di pasar modal negara-negara la in di luar Amerika Serikat (Wang, L \& Erickson 1997).

Sejumlah penjelasan telah dikembangkan untuk mengungkapkan teka-teki adanya retum negatif yang persisten pada perdagangan hari Senin. Lakonishok \& Maberly (1990) menemukan bahwa investor institusional melakukan lebih sedikit transaksi pada har Senin sementara investor individual melakukan lebih banyak transaksi dengan penjualan lebih dominan. Abraham \& Ikenberry (1994) melakukan penelitian secara lebih mendalam. Mereka menemukan bahwa tekanan jual dari 
investor secara substansial lebih tinggi jika a da info masi yang tidak baik (bad news) pada hari Jum'at yang negatif.

Rogalski (1984) menjawab fenomena tersebut dengan mengelompokkan retum harian ke dalam retum untuk trading day dan nontrading day. Berdasarkan penelitiannya, rata-rata retum negatif dari penutupan Jum'at sampai dengan penutupan Senin lebih negatif yang disebabkan oleh adanya periode nonperdagangan dari penutupan Jum'at sa mpai dengan pembukaan Senin yang lebih panjang. Inti masalah dari penelitian Rogalski tersebut membuktikan bahwa retum untuk har Senin ada lah paling rendah di anta ra retum-retum hari yang la in.

Rogalski (1984) juga menyatakan bahwa nilai retum negatif pada hari Senin hanya terjadi pada awal-awal perdagangan (30 menit awal perdagangan), tidak pada keseluruhan hari Senin. Retum close-to-open pada hari Senin (retum penutupan Jum'at sampai dengan pembukaan Senin) lebih negatif apabila dibandingkan dengan retum close-to-close (penutupan J um'at sampai dengan penutupan Senin). Bahkan nilai retum periode perdagangan pada hari Senin (open-to-close) bemilai positif. Artinya, retum har Senin pada periode nonperdagangan lebih negatif apabila dibandingkan dengan nilai absolut antara retum penutupan Jum'at sampai dengan penutupan Senin dan retum close-to-close periode perdagangan yang lainnya. Oleh karena itu, nilai retum yang negatif pada hari Senin disebabkan hanya oleh periode nonperda gangan (Rogalski 1984). Cheung (1995) membuktikan pengujiannya yang dilakukan di pasar modal Hongkong dan mendukung simpulan dari penelitian Roga lski tersebut.

Hanya saja, penelitian dalam fenomena-fenomena yang terkait dengan retum harus difokuskan pada data intraday, yakni yang mendasarkan pada kejadian transaksi nil detik per detik secara kontinyus (Huang, Liu \& Fu 2000). Konsep ini sebenamya telah dikemuka kan oleh Rogalski (1984) yang menyatakan bahwa nilai retum negatif pada hari Senin hanya terjadi pada 30 menit awal perdagangan, dan bukan tejadi pada keseluruhan hari Senin. Bukti ini mengisyaratkan bahwa penelitian day of the week dan Monday effect haruslah mengarah ke data intraday. Selanjutnya fenomena day of the week dan Monday effect ini juga perlu dikontrol terhadap ukuran perusahaan (size), volume perdagangan (trading volume) dan bentang tawar-minta (bid-ask spread).

\section{Tujuan Penelitian}

Penelitian ini menguji fenomena day of the week effect dan Monday effect di Bursa Efek Indonesia dengan menggunakan data retum intraday. Secara lebih spesifik, studi ini mengkritisi dan menguji kembali dengan metodologi penelitian yang lebih detail dan rinci (methodological refinement) atas penelitian Sumiyana (2007a). Pengembangan metodologi yang lebih baik mampu menyanggah hasil penelitian Sumiyana (2007a). 


\section{Manfaat Penelitian}

Penelitian ini bermanfaat bagi investor dan calon investor untuk menganalisis terhadap investasi dan keputusan investasi yang hendak dilakukan. Informasi yang diperolehnya berwujud perilaku variabilitas harga saham selama periode 2006. Manfaat lain dari penelitian ini adalah penyajian reliabilitas informas retum dalam kaitannya dengan keputusan yang hendak diambil oleh investor dan calon investor (FASB, SFAC No. 1, 1993).

\section{Sistematika Pembahasan}

Penelitian ini membahas dalam rangkaian urutan pembahasan sebagai berikut. Bagian 1 membahas tentang pendahuluan yang berisi kandungan konsep teoritis dan hipotesis penelitian yang telah ada, tujuan penelitian dan manfaat penelitian. Bagian 2 membahas tentang tinjauan pustaka dan pengembangan hipotesis. Bagian 3 membahas tentang metode penelitian yang digunakan untuk menguji seluruh hipotesis. Bagian 4 membahas tentang hasil dan temuan penelitian. Yang tera khir, Ba gian 5 membahas tentang simpulan yang diperoleh dari hasil analisis dan temuan peneliti.

\section{LANDASAN TEOR DAN PENGEMBANGAN HIPOTESIS}

Banyak penelitian telah menunjukkan adanya pola dalam pergerakan harga saham. Pola tersebut menunjukkan adanya tingkat retum yang lebih tinggi atau lebih rendah pada saat tertentu. Salah satu pola tersebut adalah adanya perbedaan retum untuk hari-hari tertentu dalam seminggu. Cross (1973) meneliti tentang perilaku retum saham pada har Jum'at dan senin dengan menggunakan data S\&P 500 Index selama periode 1952. Penelitian ini menemukan bukti bahwa retum saham negatif pada hari Senin. Gibbons \& Hess (1981) juga menemukan bahwa retum saham pada hari Senin akan lebih rendah dibanding hari perdagangan lainnya di NYSE. Penelitian tersebut dilakukan dengan menggunakan data harian selama periode 1962 sampai 1978, dan menemukan adanya retum yang negatif pada hari perdagangan Senin sebesar $-0.33 \%$. Selanjutnya, mereka juga membagi periode tersebut menjadi dua subperiode dan memperoleh hasil yang sama, yaitu terjadinya retum yang negatif pada hari perdagangan Senin. Lakonishok \& Maberly (1990) meneliti faktor-faktor yang dapat mempenga ruhi retum saham harian di NYSE. Hasil penelitian menunjukkan bahwa retum saham di NYSE dipengaruhi oleh pola a ktivitas perdagangan harian yang dilakukan oleh investor. Keinginan investor untuk melakukan transaksi pada hari Senin relatif lebih tinggi dibanding hari perdagangan lainnya, sehingga aktivitas transaksi pada hari Senin lebih tinggi dibanding hari lainnya. Hal ini dipicu oleh adanya hasrat investor untuk menjual saham lebih tinggi dibanding hasratnya untuk membeli saham, sehingga harga saham cendenung lebih rendah. 
Hasil penelitian yang dilakukan oleh Miller (1988) memperkuat argumentasi atas kecendenungan retum saham terrendah pada hari Senin dibanding hari perdagangan lainnya. Menurut Miller, retum saham terrendah tejadi pada perdagangan hari Senin yang disebabkan oleh lamanya akhir pekan hingga pada hari perdagangan Senin, investor memiliki kecendenungan untuk menjual saham melebihi kecendenungan untuk membeli saham. Pada perdagangan har Senin, pasar mengalami sumplus pemintaan jual (sell order) yang merupakan akumulasi dari permintaan jual selama pasar tutup pada akhir pekan.

Rystom \& Benson (1989) meneliti pengaruh hari perdagangan terhadap retum saham melalui pendekatan psikologis. Pendekatan ini diarahkan pada pengamatan terhadap perilaku perubahan harga saham yang disebabkan oleh perilaku investor individual. Menunut mereka, investor individual dalam membuat keputusan finansialnya tidak hanya dipengaruhi oleh pertimbangan rasionalitas ekonomis dan data obyektif saja, namun juga dipengaruhi oleh tindakan yang tidak rasional seperti emosi, kebiasaan psikologis tertentu dan mood investor individual. Psikologis investor tidak menyukai hari Senin (bad day) karena hari Senin merupakan hari pertama dalam seminggu. Hal ini membuat mereka sering melakukan tindakan yang tidak rasional. Tindakan yang tidak rasional dalam melakukan transaksi cenderung memperoleh retum terrendah pada hari perdagangan Senin dibanding hari perdagangan lainnya. Pola musiman mingguan ini juga didokumentasikan pada beberapa pasar Asia. Ho (1990) meneliti pola musiman intra hari untuk sepuluh pasar saham Asia Pasifik, yaitu Australia, Hongkong, Jepang, Korea, Malaysia, Selandia Baru, Filipina, Singapura, Taiwan dan Thailand. Hasil penelitiannya menunjukkan pola musim mingguan yang unik ada untuk pasar Asia Pasifik, retum Selasa yang negatif dan retum Jum'at yang positif. Penjelasan yang mungkin adalah hipotesa zone waktu yang diberikan (Ho 1990), ya itu Selasa di wilayah Asia Pasifik a da la h sa ma dengan Minggu di pasar Amerika. Aggrawal \& Rivoli (1989) juga menemukan adanya retum negatif pada hari Sela sa untuk pasar modal Hongkong, Singapura, Malaysia dan Filipina. Mereka menyatakan bahwa adanya perbedaan waktu selama 13 jam antara New York dan pasar-pasar tersebut merupakan penyebab terjadinya retum negatif pada hari Selasa. Sementara itu, Athanassakos \& Robinson (1994) dalam Cahyaningdyah (2004) mengemukakan adanya kemungkinan thin trading yang sangat tinggi di pasar modal Kanada merupakan penyebab munculnya Tuesday effect di pasar modal Kanada. Thin trading ini menyebabkan informasi yang diumumkan sepanjang akhir pekan diserap hanya oleh harga saham-saham perusahaan besar Kanada pada hari Senin dan terrefleksikan dalam harga saham perusahaan kecil dengan senjang waktu.

Barument \& Kiymaz (2001) melakukan penelitian tentang pengaruh hari perdagangan terhadap retum saham dengan menggunakan Standard and Poor's 500. Market Ind ex sela ma perio de J anuari 1973 sampai dengan Oktober 1997. Hasil penelitian menunjukkan bahwa retum tertinggi terjadi pada hari Rabu sedangkan 
retum terrendah tejadi pada hari Senin. Temuan ini juga mendukung bukti empins terdahulu tentang adanya efek akhir pekan.

Penelitian day of the week di Bursa Efek Indonesia menunjukkan hasil yang bervariasi. Algifari (1998) menguji hari perdagangan terhadap retum saham-saham LQ 45 dengan periode pengamatan Januari sampai dengan Desember 1996. Hasil penelitiannya menunjukkan bahwa hari perdagangan Selasa, Rabu dan Jum'at berpengaruh terhadap retum saham sedangkan hari perdagangan Senin dan Kamis tidak berpengaruh terhadap retum saham di BEJ. Pada hari perdagangan Senin terdapat retum positif yang artinya pada hari perdagangan Senin investor memperoleh capital gain. Namun demikian, capital gain yang diperoleh investor pada perdagangan Senin tidaklah signifikan.

Penelitian yang dilakukan oleh Cahyaning dyah (2004) selama periode Januari 2001 sampai dengan Desember 2003 menunjukkan adanya kesamaan dengan pola retum saham harian di bursa efek AS yang menunjukkan bukti bahwa rata-rata retum terrendah tejadi pada hari Senin (Monday effect) dan rata-rata retum tertinggi terjadi pada har perdagangan Jum'at (weekend effect). Hasil penelitian ini menambah bukti empins tentang pengaruh hari perdagangan terhadap retum saham di BEJ . Menurut Gibbons \& Hess (1981) fenomena retum terrendah pada har Senin (Monday effect) terjadi karena measurement error. Hal ini disebakan retum Senin hanya dihitung dari close to close Jum'at sampai Senin. Rogalski (1984) mencoba membagi retum penutupan Jum'at sampai dengan penutupan Senin menjadi dua komponen yaitu penutupan Jum'at sampai pembukaan Senin dan pembukaan Senin sampai penutupan Senin. Hasilnya menunjukkan bahwa retum Senin yang negatif terjadi pada periode non trading yaitu penutupan Jum'at sampai dengan pembukaan Senin. Sedangkan, untuk pembukaan Senin sampai dengan penutupan Senin tidak terja di retum yang nega tif.

Haris (1986) menemukan bahwa pada hari Senin terdapat retum yang negatif tetapi empat hari lainnya retumnya positif. Retum yang negatif pada har Senin tidak terjadi pada sepanjang hari itu, tetapi setengahnya tejadi pada penutupan pasar di hari Jum'at dan pembuka an pasar di hari Senin. Penurunan retum yang terbesar terjadi pada 45 menit perta ma perdagangan di hari Senin. Sesudah itu, retum di hari Senin sama dengan hari-hari lainnya. Berdasarkan temuannya tersebut menyarankan bahwa investor bertindak untuk menjual saham pada hari Jum'at dan melakukan pembelian sesudah 45 menit pertama perdagangan di har Senin. Hal ini didukung Cheung (1995) yang meneliti perilaku harga saham di pasar modal Hongkong dengan periode pengamatan 26 April 1986 sampai dengan 31 Desember 1990. Hasil penelitiannya menunjukkan bahwa Monday effect sebenamya tejadi hanya pada 30 menit pertama di hari Senin, yang tidak pada keseluruhan hari Senin. Dari hasil penelitian-penelitian di atas dapat hipotesiskan sebagai berikut. 
H: Hari perdagangan berpengaruh terhadap retum saham di Bursa Efek Indonesia

H2: Hari Senin berpengaruh terhadap retum saham di Bursa Efek Indonesia dan merupakan retum yang terrendah dalam bandingannya dengan retum hari-hari yang lain

\section{METODE PENEUTAN}

Sampel penelitian ini adalah perusahaan-perusahaan yang termasuk dalam daftar indeks LQ 45 baik pada semester pertama maupun semester kedua untuk tahun 2006. Pemiliha $n$ LQ 45 dila kukan dengan alasan bahwa perusahaan-perusahan yang masuk ke dalam LQ45 mempunyai likuiditas yang tinggi, sehingga mampu mengurangi adanya saham tidur baik pada hari perdagangan. Adanya saham yang tidak aktif mengganggu akurasi penelitian yang dilakukan ini. Metode pemilihan sampel ini dilakukan karena Bursa Efek Indonesia merupakan pasar modal yang masih dangkal (thin market) yang ditandai dengan banyaknya saham tidur (Hartono 2003, 2005).

\section{Retum}

Harga pembukaan dan penutupan untuk setiap interval 30 menitan retum terletak pada hari perdagangan yang diperoleh dari data intraday. Retum ditentukan

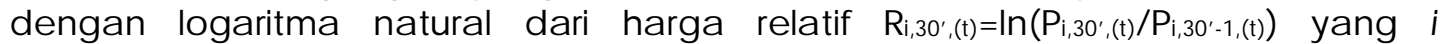
menunjukkan perusahaan dan $t$ menunjukkan har untuk masing-masing perusahaan. Untuk menghitung retum interval 30 menitan per masing-masing perusahaan diba gi menja di 12 interval, dan dalam perumusan sebagai berikut.

Retum interval 30' ke-01
Retum interval 30' ke-02
Retum interval 30' ke-03
Retum interval 30' ke-04
Retum interval 30' ke-05
Retum interval 30' ke-06
Retum interval 30' ke-07
Retum interval 30' ke-08
Retum interval 30' ke-09
Retum interval 30' ke-10
Retum interval 30' ke-11
Retum interval 30' ke-12

$$
\begin{aligned}
& : \mathrm{R}_{\mathrm{i}, 16.00(\mathrm{t}-1)-09.30(\mathrm{t})}=\ln \left(\mathrm{P}_{\mathrm{i}, 09.30(\mathrm{t})} / \mathrm{P}_{\mathrm{i}, 16.00(\mathrm{t}-1)}\right)
\end{aligned}
$$

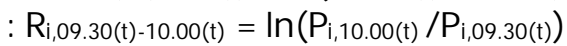

$$
\begin{aligned}
& : \mathrm{R}_{\mathrm{i}, 10.00(\mathrm{t})-10.30(\mathrm{t})}=\ln \left(\mathrm{P}_{\mathrm{i}, 10.30(\mathrm{t})} / \mathrm{P}_{\mathrm{i}, 10.00(\mathrm{t})}\right) \\
& : \mathrm{R}_{\mathrm{i}, 10.30(\mathrm{t})-11.00(\mathrm{t})}=\ln \left(\mathrm{P}_{\mathrm{i}, 11.00(\mathrm{t})} / \mathrm{P}_{\mathrm{i}, 10.30(\mathrm{t})}\right)
\end{aligned}
$$

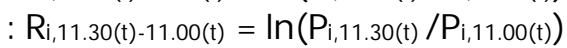

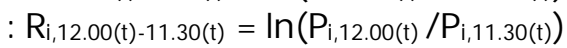

$$
\begin{aligned}
& : \mathrm{R}_{\mathrm{i}, 13.30(\mathrm{t})-13.00(\mathrm{t})}=\ln \left(\mathrm{P}_{\mathrm{i}, 13.30(\mathrm{t})} / \mathrm{P}_{\mathrm{i}, 13.00(\mathrm{t})}\right) \\
& : \mathrm{R}_{\mathrm{i}, 14.00(\mathrm{t})-13.30(\mathrm{t})}=\ln \left(\mathrm{P}_{\mathrm{i}, 14.00(\mathrm{t})} / \mathrm{P}_{\mathrm{i}, 13.30(\mathrm{t})}\right) \\
& : \mathrm{R}_{\mathrm{i}, 14.30(\mathrm{t})-14.00(\mathrm{t})}=\ln \left(\mathrm{P}_{\mathrm{i}, 14.30(\mathrm{t})} / \mathrm{P}_{\mathrm{i}, 14.00(\mathrm{t})}\right)
\end{aligned}
$$

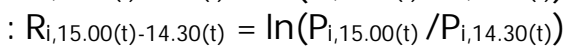

$$
\begin{aligned}
& : \mathrm{R}_{\mathrm{i}, 15.30(\mathrm{t})-15.00(\mathrm{t})}=\ln \left(\mathrm{P}_{\mathrm{i}, 15.30(\mathrm{t})} / \mathrm{P}_{\mathrm{i}, 15.00(\mathrm{t})}\right) \\
& : \mathrm{R}_{\mathrm{i}, 16.00(\mathrm{t})-15.30(\mathrm{t})}=\ln \left(\mathrm{P}_{\mathrm{i}, 16.00(\mathrm{t})} / \mathrm{P}_{\mathrm{i}, 15.30(\mathrm{t})}\right)
\end{aligned}
$$

\section{Waktu Perdagangan dan Retum}

Waktu perdagangan tidak sama untuk setiap harinya. Perdagangan dibuka pertama kali pukul 09.00. setiap harinya, tetapi untuk penutupan sesi pertama 
berakhir pukul 12.00 untuk Hari Senin sampai dengan Ka mis, sedangkan Hari J um'at ditutup pukul 11.30. Pembukaan sesi kedua pada pukul 13.30 untuk Hari Senin sampai dengan Hari Kamis, sedangkan Hari Jum'at dibuka pada pukul 14.00. Penutupan sesi kedua dilakukan pada pukul 16.00 untuk setiap harinya. Gambar 1 menunjukkan hari perdagangan dan periode perdagangan dalam kaitannya dengan pembentukan retum untuk setiap interval 30 menitan tersebut untuk hari Senin sa mpai Kamis. Sedangkan untuk Jum'at retum 12.00 dan 13.30 dihilanhkan dari ana lisis, ka rena istira hat (break) hari J um' at adlah jam 11.30-14.00.

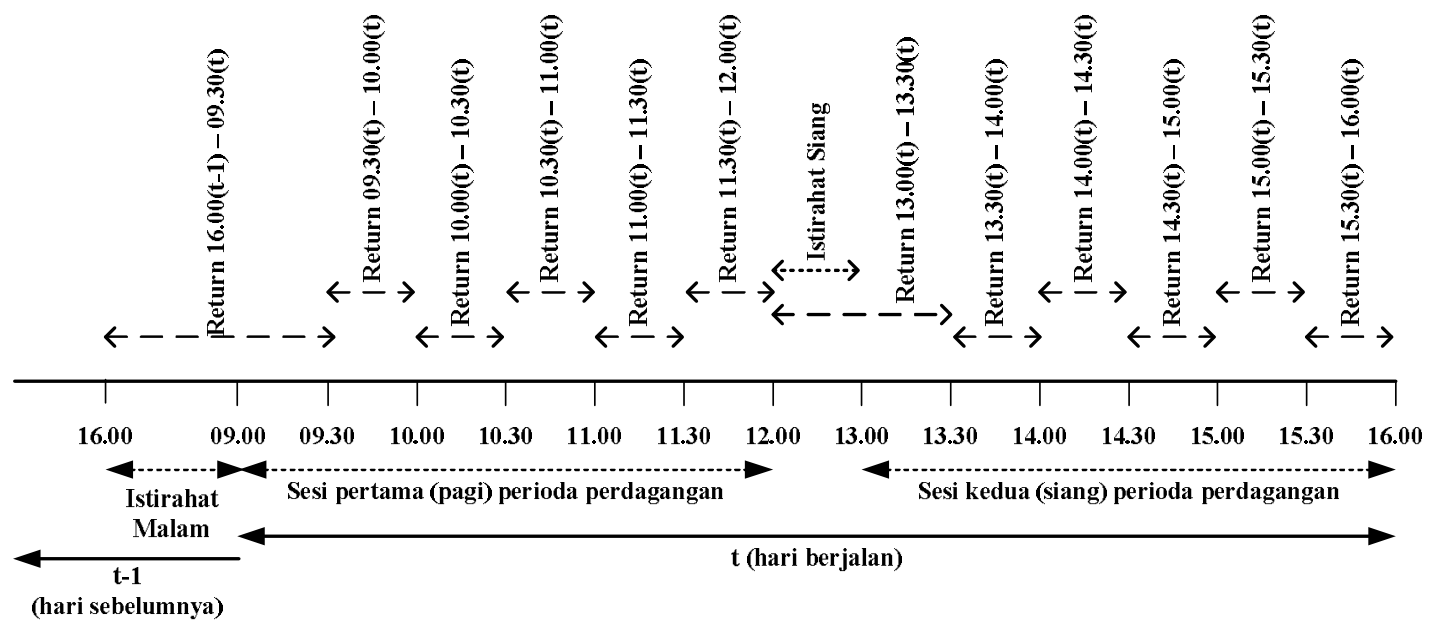

Gambar 1

Periode Transaksi di Bursa Efek Indonesia Beserta Pembagian Interval 30 Menitan

\section{Penyesuaian dan Pengendalian Basis Portofolio}

Penyesuaian dilakukan terhadap stock dividen, stock split, bonus share dan stock reserve split dan pengumuman dividen. Selanjutnya, penelitian ini melakukan pembentukan portofolio yang digunakan untuk pengendalian uji regresi dilakukan. Portofo lio pasar dibentuk dengan meto de equal-weighted denga $n$ berdasar harian. Adapun pembentukan portofolio dilakukan dengan mengambil variabel-variabel operasional, ya kni (1) ukuran penusahaan diproksikan dengan nilai ka pitalisasi pasar yang merupakan perkalian antara jumlah saham yang beredar dan harga penutupan saham akhir tahun, (2) volume perdagangan (trading volume) yang merupakan jumlah transaksi yang diperdagangkan pada satu hari, serta (3) bentang tawar-minta yang merupakan selish antara harga penawaran dan harga permintaan yang dibentuk ke dalam quintiles bentang tawar-minta dengan bentang relatif (relative spread) dengan pembagian kisaran (a) $0,00 \%-1,00 \%$, (b) $1,00-2,00 \%$, (c) 2,00\%-3,00\%, (d) 3.00-4,00\%, dan (e) lebih besar dari $4,00 \%$. 


\section{Analisis Data}

Ana lisis da ta dila kukan denga n langkah prosedural sebagai berikut:

1. Dari data intra-day diperoleh 12 seri harga ya itu ha rga berbasis interval waktu 30 menitan. Harga dalam pisah batas waktu 30 menitan tersebut digunakan untuk mengka lkula si retum.

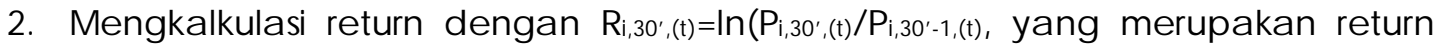
periode interval menitan dari yang pertama sampai dengan yang ke duabelas.

3. Membentuk 12 seri retum interval 30 menitan dari hari Senin sampai dengan Jum'at. Analisis di dalam pengujian hanya difokuskan untuk membedakan retum interval 30 menitan yang satu dalam bandingannya dengan intervalinterval 30 menitan yang lain.

4. Menghilangkan hari di sekitar pengumuman dividen dari sampel dengan alasan untuk mengeliminasi tejadinya fluktuasi harga yang sangat tajam $(\mathrm{H}-3$ dan $\mathrm{H}+3)$, serta melakukan penyesuaian terhadap stock dividen, stock split, bonus share dan stock reserve split.

5. Melakukan uji regresi dan pengujian statitik uji-t untuk masing-masing koefisien variabel interval waktu dengan membandingkan antara retum hari Senin sampai Jum'at dari ke dua belas retum tersebut. Pengujian regresi dilakukan dengan model tanpa konstanta. Hal ini digunakan untuk mengeliminasi penga ruh variansi multikolinearitas (Gujarati, 2003). Sehingga, perumusan model regresinya adalah sebagai berikut.

$$
R_{t}=\beta_{1} R_{\text {senin }}+\beta_{2} R_{\text {selasa }}+\beta_{3} R_{\text {Rabu }}+\beta_{4} R_{\text {Kamis }}+\beta_{5} R_{\text {jum'at }}+e_{t}
$$

Persamaan regresi tersebut dimaknakan sebagai berikut. Rt adalah retum saham pada hari $t, \beta_{1}$ adalah koefisien dummy regresi untuk hari Senin, Rsenin adalah retum Senin, RSelasa adalah retum hari Selasa dan seterusnya sampai RJum'at yang merupakan retum hari Jum'at.

Proses peregresian dilakukan dengan peletakkan variabel dummy dengan cara sebagai berikut. RSenin bemilai 1 untuk retum Senin dan bemilai 0 untuk har yang la innya, RSelasa bemilai 1 untuk retum Selasa dan bemilai 0 untuk retum hari yang la innya. Demikian juga, proses dilakukan seterusnya sampai dengan RJ um' at yang bemilai 1 untuk retum hari Jum'at dan bemilai 0 untuk retum hari yang lainnya.

Membentuk quintiles ukuran perusahaan untuk mengana lisis sensitivita s perilaku retum interval 30 menitan. Pengelompokan perusahaan dilakukan berdasar ukuran perusahaan yang dikalkulasi dengan jumlah lembar saham beredar dika likan dengan harga penutupan a khir tahun. Quintiles ukuran perusahaan ini diguna kan untuk uji sensitivitas. 
6. Membentuk quintiles untuk volume perdagangan dengan mengelompokan penusahaan berdasar volume perdagangan harian menurut volume perdagangan tahun bejalan secara keseluruhan. Selanjutnya, volume perda ganga $n$ ini diguna ka $n$ untuk pengenda li di dalam pengujian sensitivitas.

7. Membentuk quintiles untuk bentang tawar-minta dengan mengelompokan penusahaan berdasarbentang rela tif menurut persentase tertentu sebagaimana yang telah disajikan dalam subbab sebelumnya. Selanjutnya, bentang relatif ini diguna kan untuk pengenda li di dalam pengujian sensitivitas.

8. Setelah berhasil mengelompokan ke dalam lima kelompok quintiles yang sesuai dengan langkah nomor 7, 8, dan 9, selanjutnya dilakukan langkah nomor 6 kembali dengan melakukan uji regresi per masing-masing quintiles.

\section{HASL PENETIAN DAN TEMUAN}

Bagian pertama subbagian ini menguji day of the week dengan menganalisis retum yang dibentuk berdasar interval waktu 30 menitan. Sela njutnya, bagian kedua dan ketiga penelitian ini menguji dan menganalisis hubungan antara day of the week dan faktor pengendalian yang berupa ukuran perusahaan, volume perdagangan dan bentang tawar-minta. Bahasan selengka pnya adalah sebagai berikut.

\section{Statistik Deskriptif}

Statistik deskriptif menunjukkan bahwa dalam interval 30 menitan yang tejadi untuk tahun 2006 sangat bervariasi. Besaran mean retum interval 30 menitan dengan angka terrendah berada pada periode penutupan hari sebelumnya sampai dengan 09.30 sebesar -0,00093. Angka mean retum terrendah ini terletak di interval 30 menitan paling awal. Sedangkan, mean retum interval 30 menitan tertinggi berada pada periode waktu 15.30-16.00 sebesar 0,00424. Inferensi yang dapat dipetik dari besaran mean ini adalah telah tertunjukkan dengan basis statistik deskriptif bahwa mean tertinggi terletak pa da interval 30 menit tera khir di a khir hari perdagangan. Hal ini menyajikan bukti bahwa retum melonjak naik cukup tajam dalam bandingannya denga $n$ interval-interval 30 menitan sebelum-sebelumnya.

Sementara itu, jumlah observa si untuk interval 30 menitan pertama sebanyak 10.845 dan dari sebanyak ini yang dapat digunakan hanya sebanyak 9.956 atau mengeliminasi data sebanyak 889. J umlah observasi dan observasi yang digunakan berlaku sama untuk semua interval 30 menitan yang lainnya. Pengeliminasian data disebabkan oleh tidak terdapatnya transaksi yang berakibat tidak adanya perbedaan harga atau retum. Demikian seterusnya untuk data observasi dan realitas data yang digunakan di dalam penelitian sesuai dengan masing-masing interval 30 menitan.

Deviasi standar untuk masing-masing periode interval 30 menitan berkisar dalam besaran yang relatif sama. Untuk interval 30 menit periode 15.30-16.00 sebesar 
0,00708. Nilai minimum, nilai makimum dan kisaran nilai tersaji secara berturut-turut dalam kolom setelah kolom deviasi standar. Sebagi misal, nilai minimum untuk interval 30 menitan terakhir di hari perdagangan sebesar $-0,03$, nilai maksimum sebesar 0,04 dan kisaran nilai yang merupakan jarak tejauh dari nilai minimum dan nilai ma ksimum sebesar 0,07. Informa si selengka pnya tersajikan di Tabel 1.

Ta bel 1

Statistik Deskriptif

\begin{tabular}{lrrrrrrr}
\hline \multicolumn{1}{c}{ Retum } & \multicolumn{1}{c}{ Mean } & N(\$) & N(\&) & \multicolumn{1}{c}{$\begin{array}{l}\text { Dev. } \\
\text { Std. }\end{array}$} & Min & Max & Kisaran \\
\hline Periode 16.00^-09.30 & $-0,00093$ & 10.845 & 9.956 & 0,00783 & $-0,05$ & 0,02 & 0,07 \\
Periode 09.30-10.00 & 0.00050 & 10.890 & 10.029 & 0,00477 & $-0,02$ & 0,02 & 0,04 \\
Periode 10.00-10.30 & $-0,00063$ & 10.890 & 9.176 & 0,00586 & $-0,05$ & 0,02 & 0,07 \\
Periode 10.30-11.00 & 0,00041 & 10.890 & 8.639 & 0,00678 & $-0,04$ & 0,05 & 0,09 \\
Periode 11.00-11.30 & $-0,00005$ & 10.890 & 8.313 & 0,00771 & $-0,06$ & 0,05 & 0,11 \\
Periode 11.30-12.00 & 0,00055 & 8.820 & 6.464 & 0,00458 & $-0,01$ & 0,04 & 0,05 \\
Periode 12.00-13.30 & $-0,00040$ & 8.820 & 6.671 & 0,00317 & $-0,02$ & 0,01 & 0,04 \\
Periode 13.30-14.00 & $-0,00033$ & 10.890 & 9.385 & 0,00413 & $-0,02$ & 0,03 & 0,05 \\
Periode 14.00-14.30 & $-0,00041$ & 10.890 & 8.677 & 0,00808 & $-0,07$ & 0,04 & 0,11 \\
Periode 14.30-15.00 & $-0,00054$ & 10.890 & 8.456 & 0,00900 & $-0,05$ & 0,08 & 0,13 \\
Periode 15.00-15.30 & $-0,00023$ & 10.890 & 8.795 & 0,00856 & $-0,03$ & 0,05 & 0,09 \\
Periode 15.30-16.00 & 0,00424 & 10.890 & 9.735 & 0,00708 & $-0,03$ & 0,04 & 0,07 \\
\hline
\end{tabular}

Keterangan: ^: hari sebelumnya; $\mathbf{N}(\$)$ : J umla h Observasi; $\mathbf{N}(\boldsymbol{(})$ : Yang Digunakan

Pengaruh hari perdagangan menjadi teramati secara jelas dalam perspektif grafis yang tersaji ke dalam Gambar 2. Secara keselunuhan (all day) mean retum interval 30 menitan selama hari perdagangan dalam bandingannya dengan seluruh sampel tertunjukkan bahwa 30 menit terakhir menaik secara tajam serta tertinggi secara grafis. Sementara itu, mean retum interval 30 menitan awal hari perdagangan dalam bandingannya dengan seluruh sampel tertunjukkan bahwa 30 menit permulaan terrendah secara grafis. Sedangkan untuk retum hari Senin (ditunjukkan oleh garis yang berupa titik-titik) secara umum terletak di bawah rera ta harian (garis), kecuali untuk retum 11.30 dan retum 15.30. Hal ini lebih terlihat apabila dibandingkan dengan retum hari non-Senin (Selasa, Rabu, Kamis dan Jum'at) yang ditunjukkan oleh garis putus-putus.

Nilai variansi yang menunjukkan tingkat volatilitas retum saham (Gambar 3) menunjukkan bahwa pada awal perdagangan volatilitas retum pada har Senin lebih rendah a pabila dibandingkan dengan volatilitas retum saham pada hari yang lain. Pada periode 10.30 sampai 11.00 volatilitas pada har Senin relatif lebih tinggi apabila dibandingkan dengan hari-hari lain. Selanjutnya pada periode 11.30 sampai dengan 14.30 volatilitas hari Senin lebih rendah, sampai dengan periode 15.00 dan 15.30 yang menjadi relatif lebih tinggi. Pada penutupan (16.00) volatilitas pada hari Senin lebih rendah apabila dibandingkan dengan hari-hari yang lain (Selasa, Rabu, Kamis dan J um'at). 


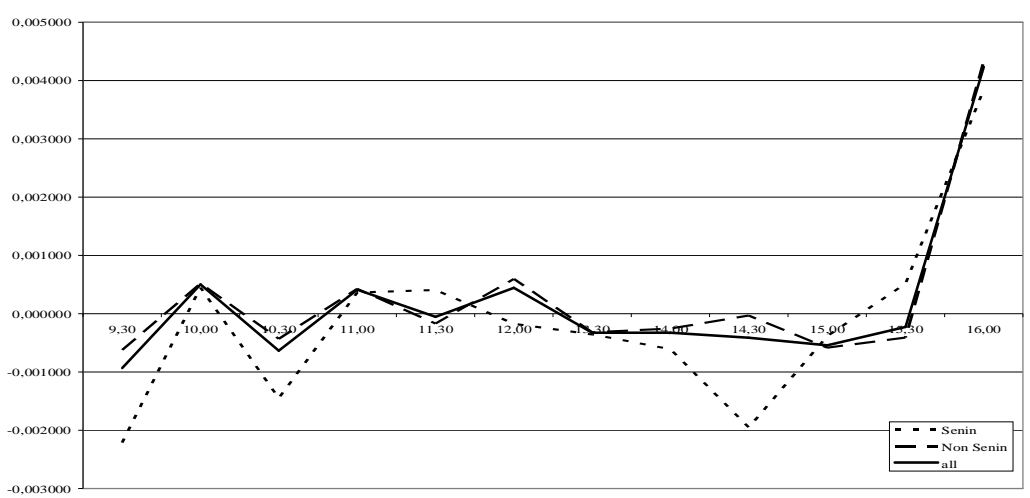

Gambar 2

Pergerakan Mean Retum dari Sampel Penuh, Senin dan Non-Senin

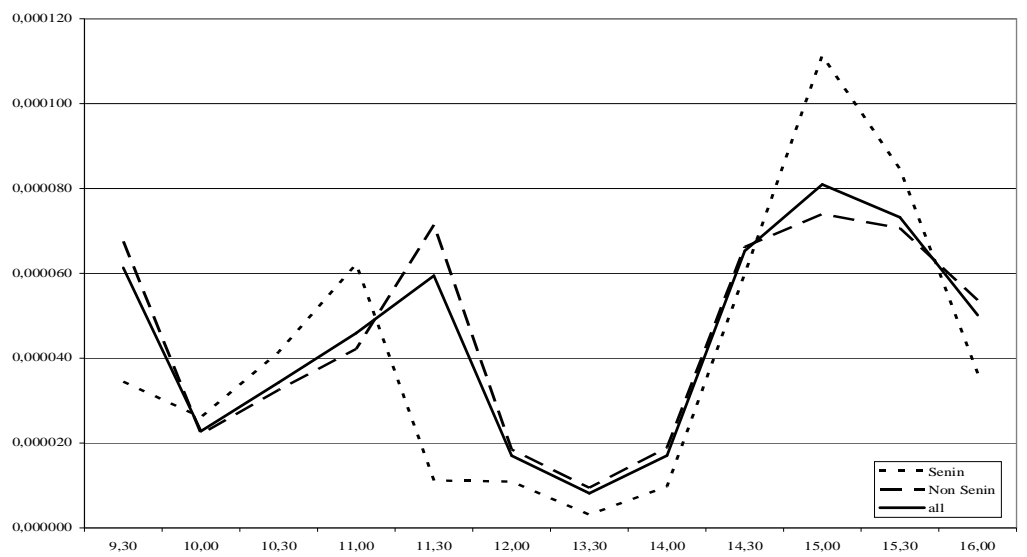

Gambar 3

Pergerakan Volatilitas dari Sampel Penuh, Senin dan Non-Senin

\section{Uji Day of the Week dan Monday Effect}

Dua belas seri retum digunakan untuk menganalisis day of the week ini, yaitu retum interval 30 menitan untuk masing-masing periode. Selanjutnya tiap periode diregresikan sendini-sendin, sehingga ada 12 regresi dengan hari sebagai variabel independennya (dummy variable). Hipotesis day of the week $\left(\mathbf{H}_{\mathbf{1}}\right)$ terdukung apabila hari berpengaruh signifikan terhadap retum. Sedangkan, hipotesis Monday effect $\left(\mathbf{H}_{\mathbf{2}}\right)$ terdukung apabila retum pada har Senin adalah paling rendah dan signifikan apabila dibandingkan dengan retum hari-hari yang lainnya. Hasil pengujian untuk seluruh sampel tertunjukkan ke dalam Tabel 2. 
Hasil uji menunjukkan bahwa pada periode pembukaan (retum 09.30) terjadi fenomena day of the week yang tertunjukkan bahwa retum 09.30 dipenga ruhi oleh hari Senin dan Selasa. Sedangkan pada periode kedua (retum 10.00) juga terjadi fenomena ini karena retum pada periode kedua ini dipengaruhi oleh hari Jum'at. Pada periode 10.30 dan 11.00 dipengaruhi oleh har Kamis. Periode 11.30 dan 12.00 dipengruhi oleh hari Rabu. Pada periode 13.30 dipengaruhi oleh hari Selasa dan Kamis. Hari Senin dan J um'at mempengaruhi retum periode 14.30. Sedangkan pada penutupan semua hari mempengaruhi retum. Fenomena day of the week tidak terjadi pada periode 14.00, 15.00 dan 15.30. Secara umum fenomena day of the week terjadi pada setiap periode, tetapi harinya tidak konsisten.

Ta bel 2

Ha sil Uji Day of the Week dan Monday Effect

\begin{tabular}{|c|c|c|c|c|c|c|}
\hline & & Senin & Selasa & Rabu & Kamis & Jumat \\
\hline \multirow[t]{3}{*}{\begin{tabular}{|l|} 
return 09.30 \\
\end{tabular}} & Mean & $-22,1180$ & $-18,1290$ & $-4,2907$ & 1,1930 & $-14,5760$ \\
\hline & Std Dev & 5,8700 & 6,6170 & 7,0680 & 10,0100 & 8,7710 \\
\hline & $t$-value & $-1,9440 *$ & $-1,6270 *$ & $-0,3930$ & 1,0600 & $-1,2680$ \\
\hline \multirow[t]{3}{*}{ return 10.00} & Mean & 0,4468 & 0,5218 & 0,5485 & $-3,3654$ & 1,3680 \\
\hline & Std Dev & 5,1090 & 4,4840 & 4,9550 & 4,0590 & 5,2270 \\
\hline & $t$-value & 0,6470 & 0,7640 & 0,8190 & $-0,4870$ & $1,9400 *$ \\
\hline \multirow[t]{3}{*}{ return 10.30 } & Mean & $-14,5140$ & $-9,7975$ & 0,2729 & $-16,5240$ & 0,6398 \\
\hline & Std Dev & 6,4370 & 4,2470 & 3,2390 & 8,7600 & 4,9750 \\
\hline & $t$-value & $-1,7240 *$ & $-1,1760$ & 0,3340 & $-1,9630 *$ & 0,7440 \\
\hline \multirow[t]{3}{*}{ return 11.00 } & Mean & 0,3634 & 0,4425 & 0,1167 & 1,8030 & $-6,8968$ \\
\hline & Std Dev & 7,8860 & 7,3140 & 4,4430 & 6,7810 & 7,1070 \\
\hline & $t$-value & 0,3710 & 0,4570 & 0,1230 & $1,8410 *$ & $-0,6890$ \\
\hline \multirow[t]{3}{*}{ return 11.30} & Mean & 0,4087 & 0,4498 & $-20,6950$ & $-4,2493$ & 1,5460 \\
\hline & Std Dev & 3,3420 & 8,3380 & 10,3300 & 5,3740 & 8,7100 \\
\hline & $t$-value & 0,3690 & 0,4100 & $-1,9250 *$ & $-0,3830$ & 1,3650 \\
\hline \multirow[t]{3}{*}{ return 12.00} & Mean & $-1,7255$ & 0,6705 & 1,1670 & 0,4906 & \\
\hline & Std Dev & 3,3040 & 3,3220 & 7,0030 & 3,4170 & \\
\hline & $t$-value & $-0,2890$ & 1,1360 & $2,0180 * *$ & 0,8230 & \\
\hline \multirow[t]{3}{*}{ return 13.30 } & Mean & $-3,5597$ & $-17,9050$ & $-1,3886$ & 0,6826 & \\
\hline & Std Dev & 1,7700 & 4,8330 & 2,5190 & 2,1820 & \\
\hline & $t$-value & $-0,8930$ & $-4,5360 * * *$ & $-0,3590$ & $1,7120 *$ & \\
\hline \multirow[t]{3}{*}{ return 14.00} & Mean & $-6,0953$ & $-4,9905$ & $-1,8940$ & $-2,6171$ & $-0,6313$ \\
\hline & Std Dev & 3,1180 & 5,9920 & 3,9860 & 4,1800 & 2,6200 \\
\hline & $t$-value & $-1,0150$ & $-0,8390$ & $-0,3250$ & $-0,4360$ & $-0,1030$ \\
\hline \multirow[t]{3}{*}{ return 14.30} & Mean & $-19,5370$ & 1,1750 & 0,7781 & $-1,9257$ & $-20,4750$ \\
\hline & Std Dev & 7,7340 & 6,6850 & 6,4300 & 6,8870 & 11,5900 \\
\hline & $t$-value & $-1,6850 *$ & 1,0230 & 0,6920 & $-0,1660$ & $-1,7280 *$ \\
\hline \multirow[t]{3}{*}{ return 15.00} & Mean & $-3,8604$ & $-14,9380$ & $-14,1970$ & $-11,2860$ & 1,8860 \\
\hline & Std Dev & 10,5500 & 5,9520 & 9,3060 & 5,5910 & 11,9300 \\
\hline & $t$-value & $-0,2980$ & $-1,1640$ & $-1,1280$ & $-0,8700$ & 1,4230 \\
\hline \multirow[t]{3}{*}{ return 15.30} & Mean & 0,5134 & $-2,1512$ & $-0,6453$ & $-4,1463$ & $-9,9568$ \\
\hline & Std Dev & 9,1980 & 9,0060 & 10,1100 & 8,0820 & 5,8470 \\
\hline & $t$-value & 0,4130 & $-0,1750$ & $-0,0530$ & $-0,3330$ & $-0,7840$ \\
\hline \multirow[t]{3}{*}{ return 16.00} & Mean & 3,8460 & 4,6960 & 4,3780 & 3,9580 & 4,2810 \\
\hline & Std Dev & 6,0350 & 9,7290 & 7,0960 & 5,7350 & 6,2270 \\
\hline & $t$-value & $3,7350 * * *$ & $4,6080 * * *$ & $4,3820 * * *$ & $3,8440 * * *$ & $4,0690 * * *$ \\
\hline
\end{tabular}

Keterangan:

*signifikan pada level 10,00\%; **signifika n pada level 5,00\%; ***signifika n pada level 1,00\% 
Fenomena Monday Effect terjadi jika retum hari Senin menupakan retum terkecil dibandingkan dengan retum hari-hari lain dan hari Senin mempengaruhi retum. Retum terkecil yang terjadi pada hari Senin terdapat pada periode 09.30, 12.00 dan 16.00 , teta pi pada periode 12.00 hari Senin tidak mempengaruhi retum. Oleh karena itu, fenomena Monday Effect hanya terjadi pada harga pembukaan dan harga penutupan (retum 09.30 dan retum 16.00). Ha sil selengkapnya tersaji pada Tabel 3.

Ta bel 3

Reka pitula si Hasil Uji Day of the Week dan Monday Effect

\begin{tabular}{|c|c|c|c|c|c|c|c|c|}
\hline Peroide & Senin & Selasa & Rabu & Kamis & J umat & $\begin{array}{c}\text { Day of } \\
\text { the } \\
\text { Week }\end{array}$ & $\begin{array}{l}\text { Retum } \\
\text { Terkecil }\end{array}$ & $\begin{array}{c}\text { Monday } \\
\text { Effect }\end{array}$ \\
\hline Retum 09.30 & $*$ & * & & & & $*$ & Senin & $*$ \\
\hline Retum 10.00 & & & & & $*$ & $*$ & Kamis & \\
\hline Retum 10.30 & * & & & $*$ & & $*$ & Kamis & \\
\hline Retum 11.00 & & & & * & & * & Jumat & \\
\hline Retum 11.30 & & & $*$ & & & $*$ & Rabu & \\
\hline Retum 12.00 & & & $* *$ & & & ** & Senin & \\
\hline Retum 13.30 & & $* 11 k$ & & $*$ & & 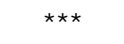 & Sela sa & \\
\hline Retum 14.00 & & & & & & & Senin & \\
\hline Retum 14.30 & $*$ & & & & $*$ & $*$ & Jumat & \\
\hline Retum 15.00 & & & & & & & Selasa & \\
\hline Retum 15.30 & & & & & & & Jumat & \\
\hline Retum 16.00 & *1kk & $* 1+k$ & $* 1+k$ & 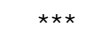 & $* * *$ & $* * k$ & Senin & **k \\
\hline
\end{tabular}

Keterangan:

*signifikan pada level 10,00\%; **signifikan pada level 5,00\%; ***signifikan pa da level 1,00\%

\section{Pengendalian dengan Basis Ukuran Perusahaan}

Fama \& French (1992) menunjukkan bahwa ukuran perusahaan lebih konsisten dan signifikan dibandingkan dengan beta dalam mempengaruhi retum. Hubungan antara ukuran perusahaan dan retum merupakan hubungan yang berkebalikan. Saham-saham dari perusahaan yang lebih kecil cenderung mempunyai retum yang lebih tinggi daripada saham-saham dari penusahaan yang lebih besar, sehingga investor akan memilih small fim jika dia mempertimbangkan faktor ukuran perusahaan.

Saham penusahaan dengan ukuran perusahaan kecil mempunyai tingkat frekuensi perdagangan tidak secepat dan tidak semudah saham perusahaan dengan ukuran perusahaan besar. Perusahaan dengan ukuran perusahaan kecil sangat riskan terhadap perubahan kondisi ekonomi dan cenderung kurang menguntungkan dibandingkan dengan perusahaan besar. Oleh karena itu saham dari perusahaan yang mempunyai ukuran perusahaan kecil akan menanggung risiko yang lebih besar. Adanya risiko yang lebih besar ini, perusahaan yang mempunyai ukuran perusahaan kecil dituntut memberikan retum yang lebih besar. 
Oleh karena itu, variabel ukuran perusahaan merupakan suatu variabel kendali yang dapat digunakan untuk meneliti fenomena day of the week.

Ta bel 4

Ha sil Uji Day of the Week yang Dikendalikan dengan Ukuran Perusa haan

\begin{tabular}{|c|c|c|c|c|c|c|c|}
\hline \multirow{4}{*}{\begin{tabular}{|l|} 
Terkecil \\
return 09.30
\end{tabular}} & & Senin & Selasa & Rabu & Kamis & Jumat & \\
\hline & Mean & $-0,0004$ & 0,0003 & 0,0016 & 0,0016 & 0,0003 & \\
\hline & Std Dev & 0,0062 & 0,0074 & 0,0078 & 0,0101 & 0,0078 & \\
\hline & $t$-value & $-0,3300$ & 0,2420 & 1,4280 & 1,3510 & 0,2980 & \\
\hline \multirow[t]{3}{*}{ return 10.00} & Mean & 0,0020 & 0,0020 & 0,0013 & 0,0004 & 0,0035 & \\
\hline & Std Dev & 0,0061 & 0,0067 & 0,0065 & 0,0061 & 0,0065 & \\
\hline & $t$-value & $2,1460 * *$ & $2,1900 * *$ & 1,4560 & 0,4590 & 3,7450 & $* * *$ \\
\hline \multirow[t]{3}{*}{ return 10.30} & Mean & $-0,0010$ & 0,0003 & 0,0006 & $-0,0031$ & 0,0001 & \\
\hline & Std Dev & 0,0045 & 0,0044 & 0,0051 & 0,0184 & 0,0044 & \\
\hline & t-value & $-0,7610$ & 0,2640 & 0,4600 & $-2,3340 * *$ & 0,0710 & \\
\hline \multirow[t]{3}{*}{ return 11.00} & Mean & $-0,0001$ & $-0,0007$ & 0,0003 & 0,0000 & $-0,0003$ & \\
\hline & Std Dev & 0,0045 & 0,0064 & 0,0062 & 0,0170 & 0,0036 & \\
\hline & $t$-value & $-0,0470$ & $-0,5680$ & 0,2090 & 0,0230 & $-0,2120$ & \\
\hline \multirow[t]{3}{*}{ return 11.30} & Mean & $-0,0001$ & $-0,0001$ & $-0,0035$ & $-0,0004$ & 0,0009 & \\
\hline & Std Dev & 0,0042 & 0,0071 & 0,0206 & 0,0158 & 0,0047 & \\
\hline & t-value & $-0,0360$ & $-0,0440$ & $-1,9730 * *$ & $-0,2030$ & 0,4710 & \\
\hline \multirow[t]{3}{*}{ return 12.00} & Mean & 0,0000 & $-0,0003$ & 0,0003 & $-0,0004$ & & \\
\hline & Std Dev & 0,0044 & 0,0089 & 0,0048 & 0,0032 & & \\
\hline & t-value & $-0,0420$ & $-0,3130$ & 0,3670 & $-0,4510$ & & \\
\hline \multirow[t]{3}{*}{ return 13.30} & Mean & 0,0003 & $-0,0031$ & 0,0011 & 0,0009 & & \\
\hline & Std Dev & 0,0040 & 0,0170 & 0,0058 & 0,0025 & & \\
\hline & t-value & 0,2280 & $-2,3090 * *$ & 0,8480 & 0,6450 & & \\
\hline \multirow[t]{3}{*}{ return 14.00} & Mean & $-0,0004$ & 0,0014 & $-0,0009$ & 0,0000 & 0,0003 & \\
\hline & Std Dev & 0,0050 & 0,0171 & 0,0043 & 0,0041 & 0,0027 & \\
\hline & t-value & $-0,3160$ & 1,1410 & $-0,7250$ & 0,0140 & 0,2700 & \\
\hline return 14.30 & Mean & $-0,0005$ & 0,0004 & $-0,0010$ & $-0,0003$ & 0,0001 & \\
\hline & Std Dev & 0,0048 & 0,0074 & 0,0150 & 0,0068 & 0,0036 & \\
\hline & t-value & $-0,3860$ & 0,3490 & $-0,8460$ & $-0,2120$ & 0,0870 & \\
\hline return 15.00 & Mean & $-0,0036$ & $-0,0023$ & $-0,0030$ & $-0,0013$ & 0,0000 & \\
\hline & Std Dev & 0,0179 & 0,0091 & 0,0299 & 0,0085 & 0,0049 & \\
\hline & $t$-value & $-1,4830$ & $-0,9360$ & $-1,2510$ & $-0,5280$ & $-0,0080$ & \\
\hline \begin{tabular}{|l|l} 
return 15.30 \\
\end{tabular} & Mean & 0,0014 & $-0,0014$ & 0,0036 & $-0,0010$ & $-0,0023$ & \\
\hline & Std Dev & 0,0185 & 0,0123 & 0,0335 & 0,0082 & 0,0074 & \\
\hline & t-value & 0,5040 & $-0,5120$ & 1,3670 & $-0,3740$ & $-0,8150$ & \\
\hline return 16.00 & Mean & 0,0023 & 0,0050 & 0,0032 & 0,0019 & 0,0029 & \\
\hline & Std Dev & 0,0074 & 0,0124 & 0,0091 & 0,0077 & 0,0075 & \\
\hline & t-value & $1,7240 *$ & 3,8740 **** & $2,5520 * *$ & 1,4690 & 2,1930 & $* *$ \\
\hline $\mathbf{B}$ & & Senin & Selasa & Rabu & Kamis & Jumat & \\
\hline return 09.30 & Mean & $-0,0015$ & $-0,0021$ & $-0,0001$ & 0,0021 & $-0,0039$ & \\
\hline & Std Dev & 0,0064 & 0,0094 & 0,0061 & 0,0103 & 0,0213 & \\
\hline & t-value & $-0,8480$ & $-1,2620$ & $-0,0490$ & 1,2070 & $-2,2130$ & $* *$ \\
\hline return 10.00 & Mean & 0,0011 & 0,0004 & 0,0008 & $-0,0004$ & 0,0020 & \\
\hline & Std Dev & 0,0058 & 0,0053 & 0,0055 & 0,0049 & 0,0055 & \\
\hline & $t$-value & 1,4660 & 0,5690 & 1,0220 & $-0,5530$ & 2,4610 & *** \\
\hline \begin{tabular}{|l|} 
return 10.30 \\
\end{tabular} & Mean & $-0,0016$ & $-0,0011$ & 0,0003 & $-0,0018$ & 0,0007 & \\
\hline & Std Dev & 0,0057 & 0,0072 & 0,0035 & 0,0133 & 0,0061 & \\
\hline & t-value & $-1,4410$ & $-0,9900$ & 0,2410 & $-1,6040$ & 0,6280 & \\
\hline return 11.00 & Mean & $-0,0003$ & 0,0010 & 0,0004 & 0,0029 & $-0,0001$ & \\
\hline & Std Dev & 0,0053 & 0,0083 & 0,0035 & 0,0169 & 0,0087 & \\
\hline & t-value & $-0,1810$ & 0,7200 & 0,3090 & $2,0840 * *$ & $-0,0350$ & \\
\hline return 11.30 & Mean & 0,0011 & 0,0000 & 0,0004 & $-0,0022$ & $-0,0005$ & \\
\hline & Std Dev & 0,0081 & 0,0064 & 0,0077 & 0,0124 & 0,0054 & \\
\hline & $t$-value & 0,9500 & $-0,0100$ & 0,3100 & $-1,8100 *$ & $-0,3710$ & \\
\hline \begin{tabular}{|l|l} 
return 12.00 \\
\end{tabular} & Mean & $-0,0010$ & 0,0007 & $-0,0006$ & 0,0014 & & \\
\hline & Std Dev & 0,0073 & 0,0040 & 0,0057 & 0,0111 & & \\
\hline & $t$-value & $-0,9720$ & 0,6510 & $-0,5290$ & 1,2590 & & \\
\hline return 13.30 & Mean & $-0,0002$ & $-0,0013$ & $-0,0006$ & 0,0008 & & \\
\hline & Std Dev & 0,0024 & 0,0058 & 0,0028 & 0,0028 & & \\
\hline & t-value & $-0,4450$ & $-2,4120 * *$ & $-1,1290$ & 1,5570 & & \\
\hline return 14.00 & Mean & $-0,0009$ & $-0,0005$ & 0,0002 & 0,0000 & 0,0009 & \\
\hline & Std Dev & 0,0036 & 0,0069 & 0,0032 & 0,0043 & 0,0085 & \\
\hline & $t$-value & $-1,1180$ & $-0,5940$ & 0,2930 & 0,0500 & 1,1110 & \\
\hline \begin{tabular}{|l|l|} 
return 14.30 \\
\end{tabular} & Mean & $-0,0004$ & 0,0003 & 0,0000 & $-0,0008$ & $-0,0063$ & \\
\hline & Std Dev & 0,0051 & 0,0076 & 0,0040 & 0,0048 & 0,0273 & \\
\hline & t-value & $-0,2190$ & 0,1610 & 0,0260 & $-0,4120$ & $-3,3080$ & $* * *$ \\
\hline return 15.00 & Mean & 0,0006 & 0,0001 & $-0,0009$ & $-0,0007$ & 0,0054 & \\
\hline & Std Dev & 0,0050 & 0,0064 & 0,0060 & 0,0075 & 0,0273 & \\
\hline & t-value & 0,3370 & 0,0290 & $-0,5090$ & $-0,3620$ & 2,7670 & **** \\
\hline return 15.30 & & $-0,0009$ & 0,0011 & $-0,0009$ & 0,0001 & $-0,0010$ & \\
\hline & Std Dev & 0,0147 & 0,0094 & 0,0108 & 0,0130 & 0,0156 & \\
\hline & $t$-value & $-0,4670$ & 0,5760 & $-0,4950$ & 0,0690 & $-0,5210$ & \\
\hline return 16.00 & Mean & 0,0031 & 0,0019 & 0,0032 & 0,0027 & 0,0030 & \\
\hline & Std Dev & 0,0142 & 0,0105 & 0,0107 & 0,0059 & 0,0156 & \\
\hline & $t$-value & $1,8180 *$ & 1,1060 & $1,9640 *$ & 1,5560 & 1,6960 & 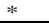 \\
\hline
\end{tabular}


Lanjutan Tabel

\begin{tabular}{|c|c|c|c|c|c|c|}
\hline $\mathbf{C}$ & & Senin & Selasa & Rabu & Kamis & Jumat \\
\hline return 09.30 & $\begin{array}{l}\text { Mean } \\
\text { Std Dev } \\
t \text {-value }\end{array}$ & $\begin{array}{l}-0,0028 \\
0,0065 \\
-2,3020 \text { * }{ }^{2} *\end{array}$ & $\begin{array}{r}-0,0014 \\
0,0071 \\
-1,2230 \\
\end{array}$ & $\begin{array}{r}-0,0014 \\
0,0083 \\
-1,1890 \\
\end{array}$ & $\begin{array}{l}0,0004 \\
0,0108 \\
0,3350 \\
\end{array}$ & $\begin{array}{r}-0,0010 \\
0,0080 \\
-0,8160 \\
\end{array}$ \\
\hline return 10.00 & $\begin{array}{l}\text { Mean } \\
\text { Std Dev } \\
\text { t-value }\end{array}$ & $\begin{array}{l}0,0005 \\
0,0065 \\
0,5160\end{array}$ & $\begin{array}{r}-0,0009 \\
0,0067 \\
-0,9210\end{array}$ & $\begin{array}{l}0,0012 \\
0,0075 \\
1,2230\end{array}$ & $\begin{array}{r}-0,0008 \\
0,0064 \\
-0,7790\end{array}$ & $\begin{array}{l}0,0008 \\
0,0066 \\
0,7710 \\
\end{array}$ \\
\hline return 10.30 & $\begin{array}{l}\text { Mean } \\
\text { Std Dev } \\
t \text {-value }\end{array}$ & $\begin{array}{r}-0,0016 \\
0,0046 \\
-2,3930 * *\end{array}$ & $\begin{array}{c}-0,0011 \\
0,0047 \\
-1,7580 *\end{array}$ & $\begin{array}{r}-0,0001 \\
0,0047 \\
-0,0980\end{array}$ & $\begin{array}{l}0,0007 \\
0,0044 \\
1,0360\end{array}$ & $\begin{array}{l}0,0010 \\
0,0040 \\
1,5610\end{array}$ \\
\hline return 11.00 & $\begin{array}{l}\text { Mean } \\
\text { Std Dev } \\
t \text {-value }\end{array}$ & $\begin{array}{r}-0,0008 \\
0,0066 \\
-0,9660 \\
\end{array}$ & $\begin{array}{l}0,0011 \\
0,0056 \\
1,3630 \\
\end{array}$ & $\begin{array}{l}0,0005 \\
0,0045 \\
0,6530 \\
\end{array}$ & $\begin{array}{l}0,0007 \\
0,0045 \\
0,8090 \\
\end{array}$ & $\begin{array}{l}0,0005 \\
0,0065 \\
0,6380 \\
\end{array}$ \\
\hline return 11.30 & $\begin{array}{l}\text { Mean } \\
\text { Std Dev } \\
t \text {-value }\end{array}$ & $\begin{array}{r}-0,0002 \\
0,0071 \\
-0,1000 \\
\end{array}$ & $\begin{array}{r}-0,0002 \\
0,0062 \\
-0,1240 \\
\end{array}$ & $\begin{array}{c}-0,0037 \\
0,0270 \\
-1,9330 * \\
\end{array}$ & $\begin{array}{r}-0,0012 \\
0,0089 \\
-0,6030 \\
\end{array}$ & $\begin{array}{r}-0,0002 \\
0,0049 \\
-0,1220 \\
\end{array}$ \\
\hline return 12.00 & $\begin{array}{l}\text { Mean } \\
\text { Std Dev } \\
t \text {-value }\end{array}$ & $\begin{array}{r}-0,0003 \\
0,0058 \\
-0,1620 \\
\end{array}$ & $\begin{array}{l}0,0016 \\
0,0059 \\
0,9470 \\
\end{array}$ & $\begin{array}{l}0,0023 \\
0,0203 \\
1,4220 \\
\end{array}$ & $\begin{array}{l}0,0004 \\
0,0073 \\
0,2520 \\
\end{array}$ & \\
\hline return 13.30 & $\begin{array}{l}\text { Mean } \\
\text { Std Dev } \\
t \text {-value }\end{array}$ & $\begin{array}{r}-0,0004 \\
0,0038 \\
-0,7470 \\
\end{array}$ & $\begin{array}{r}-0,0012 \\
0,0046 \\
-2,3320 * * \\
\end{array}$ & $\begin{array}{r}-0,0005 \\
0,0030 \\
-0,9790 \\
\end{array}$ & $\begin{array}{l}0,0004 \\
0,0034 \\
0,7540 \\
\end{array}$ & \\
\hline return 14.00 & $\begin{array}{l}\text { Mean } \\
\text { Std Dev } \\
t \text {-value }\end{array}$ & $\begin{array}{l}0,0006 \\
0,0053 \\
0,8180 \\
\end{array}$ & $\begin{array}{r}-0,0004 \\
0,0068 \\
-0,5730 \\
\end{array}$ & $\begin{array}{r}-0,0002 \\
0,0056 \\
-0,2170\end{array}$ & $\begin{array}{l}0,0005 \\
0,0047 \\
0,7240 \\
\end{array}$ & $\begin{array}{r}-0,0001 \\
0,0027 \\
-0,0660 \\
\end{array}$ \\
\hline return 14.30 & $\begin{array}{l}\text { Mean } \\
\text { Std Dev } \\
t \text {-value }\end{array}$ & $\begin{array}{l}-0,0017 \\
0,0058 \\
-2,0100 \text { 水水 }\end{array}$ & $\begin{array}{l}0,0011 \\
0,0070 \\
1,2820 \\
\end{array}$ & $\begin{array}{l}0,0015 \\
0,0064 \\
1,8300 *\end{array}$ & $\begin{array}{r}-0,0008 \\
0,0057 \\
-0,9090 \\
\end{array}$ & $\begin{array}{l}0,0005 \\
0,0037 \\
0,6170 \\
\end{array}$ \\
\hline return 15.00 & $\begin{array}{l}\text { Mean } \\
\text { Std Dev } \\
t \text {-value }\end{array}$ & $\begin{array}{l}0,0000 \\
0,0072 \\
0,0320 \\
\end{array}$ & $\begin{array}{r}-0,0003 \\
0,0069 \\
-0,3690 \\
\end{array}$ & $\begin{array}{r}-0,0011 \\
0,0079 \\
-1,1990 \\
\end{array}$ & $\begin{array}{r}-0,0003 \\
0,0049 \\
-0,3680 \\
\end{array}$ & $\begin{array}{r}-0,0008 \\
0,0044 \\
-0,8670 \\
\end{array}$ \\
\hline return 15.30 & $\begin{array}{l}\text { Mean } \\
\text { Std Dev } \\
\text { t-value }\end{array}$ & $\begin{array}{r}0,0000 \\
0,0087 \\
-0,0140\end{array}$ & $\begin{array}{r}-0,0001 \\
0,0106 \\
-0,0670\end{array}$ & $\begin{array}{r}-0,0007 \\
0,0094 \\
-0,6070\end{array}$ & $\begin{array}{r}-0,0018 \\
0,0073 \\
-1,4620\end{array}$ & $\begin{array}{r}-0,0002 \\
0,0065 \\
-0,1260\end{array}$ \\
\hline return 16.00 & $\begin{array}{l}\text { Mean } \\
\text { Std Dev } \\
t \text {-value } \\
\end{array}$ & $\begin{array}{l}0,0033 \\
0,0075 \\
2,9100 \text { 水水 } \\
\end{array}$ & $\begin{array}{l}0,0044 \\
0,0103 \\
3,9680 \text { 水水 } \\
\end{array}$ & 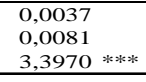 & $\begin{array}{l}0,0047 \\
0,0064 \\
4,1930 \text { 水水水 } \\
\end{array}$ & $\begin{array}{l}0,0049 \\
0,0059 \\
4,2230 \text { *水水 } \\
\end{array}$ \\
\hline $\mathbf{D}$ & & Senin & Selasa & Rabu & Kamis & Jumat \\
\hline return 09.30 & $\begin{array}{l}\text { Mean } \\
\text { Std Dev } \\
t \text {-value }\end{array}$ & $\begin{array}{r}-0,0035 \\
0,0075 \\
-2,3510 * *\end{array}$ & $\begin{array}{r}-0,0032 \\
0,0075 \\
-2,1870 * *\end{array}$ & $\begin{array}{r}-0,0021 \\
0,0084 \\
-1,4410 \\
\end{array}$ & $\begin{array}{l}0,0014 \\
0,0140 \\
0,9700\end{array}$ & $\begin{array}{r}-0,0021 \\
0,0123 \\
-1,4130 \\
\end{array}$ \\
\hline return 10.00 & $\begin{array}{l}\text { Mean } \\
\text { Std Dev } \\
t \text {-value }\end{array}$ & $\begin{array}{r}-0,0011 \\
0,0099 \\
-0,9600 \\
\end{array}$ & $\begin{array}{r}-0,0002 \\
0,0059 \\
-0,2150 \\
\end{array}$ & $\begin{array}{r}-0,0008 \\
0,0065 \\
-0,7490 \\
\end{array}$ & $\begin{array}{r}-0,0015 \\
0,0067 \\
-1,2700 \\
\end{array}$ & $\begin{array}{r}-0,0011 \\
0,0099 \\
-0,9510 \\
\end{array}$ \\
\hline return 10.30 & $\begin{array}{l}\text { Mean } \\
\text { Std Dev } \\
t \text {-value }\end{array}$ & $\begin{array}{r}-0,0032 \\
0,0299 \\
-1,2980 \\
\end{array}$ & $\begin{array}{r}-0,0024 \\
0,0116 \\
-0,9890 \\
\end{array}$ & $\begin{array}{l}0,0008 \\
0,0063 \\
0,3130 \\
\end{array}$ & $\begin{array}{r}-0,0015 \\
0,0155 \\
-0,6160 \\
\end{array}$ & $\begin{array}{l}0,0002 \\
0,0134 \\
0,0820\end{array}$ \\
\hline return 11.00 & $\begin{array}{l}\text { Mean } \\
\text { Std Dev } \\
t \text {-value }\end{array}$ & $\begin{array}{l}0,0043 \\
0,0415 \\
0,9070\end{array}$ & $\begin{array}{l}0,0028 \\
0,0169 \\
0,6100\end{array}$ & $\begin{array}{r}0,0019 \\
0,0133 \\
-0,4220\end{array}$ & $\begin{array}{l}0,0020 \\
0,0187 \\
0,4170\end{array}$ & $\begin{array}{r}-0,0068 \\
0,0543 \\
-1,4070\end{array}$ \\
\hline return 11.30 & $\begin{array}{l}\text { Mean } \\
\text { Std Dev } \\
t \text {-value }\end{array}$ & $\begin{array}{l}0,0004 \\
0,0070 \\
0,1360 \\
\end{array}$ & $\begin{array}{r}-0,0005 \\
0,0127 \\
-0,1450 \\
\end{array}$ & $\begin{array}{l}0,0020 \\
0,0120 \\
0,6490 \\
\end{array}$ & $\begin{array}{l}0,0003 \\
0,0117 \\
0,0940 \\
\end{array}$ & $\begin{array}{l}0,0074 \\
0,0448 \\
2,3030 * *\end{array}$ \\
\hline return 12.00 & $\begin{array}{l}\text { Mean } \\
\text { Std Dev } \\
t \text {-value }\end{array}$ & $\begin{array}{r}-0,0004 \\
0,0080 \\
-0,4510 \\
\end{array}$ & $\begin{array}{l}0,0010 \\
0,0052 \\
1,0960 \\
\end{array}$ & $\begin{array}{r}-0,0005 \\
0,0054 \\
-0,4950\end{array}$ & $\begin{array}{l}0,0004 \\
0,0076 \\
0,4480\end{array}$ & \\
\hline return 13.30 & $\begin{array}{l}\text { Mean } \\
\text { Std Dev } \\
t \text {-value }\end{array}$ & $\begin{array}{r}-0,0012 \\
0,0037 \\
-1,0160 \\
\end{array}$ & $\begin{array}{r}-0,0020 \\
0,0098 \\
-1,7270 * \\
\end{array}$ & $\begin{array}{r}-0,0009 \\
0,0094 \\
-0,8180 \\
\end{array}$ & $\begin{array}{l}0,0020 \\
0,0081 \\
1,6990 *\end{array}$ & \\
\hline return 14.00 & $\begin{array}{l}\text { Mean } \\
\text { Std Dev } \\
t \text {-value }\end{array}$ & $\begin{array}{r}-0,0011 \\
0,0050 \\
-0,7890\end{array}$ & $\begin{array}{r}-0,0015 \\
0,0084 \\
-1,0490\end{array}$ & $\begin{array}{l}0,0013 \\
0,0100 \\
0,9350\end{array}$ & $\begin{array}{r}-0,0043 \\
0,0138 \\
-2,9690 \text { **** }\end{array}$ & $\begin{array}{r}-0,0011 \\
0,0110 \\
-0,7430\end{array}$ \\
\hline \begin{tabular}{|l|} 
return 14.30 \\
\end{tabular} & $\begin{array}{l}\text { Mean } \\
\text { Std Dev } \\
t \text {-value }\end{array}$ & $\begin{array}{r}-0,0028 \\
0,0138 \\
-0,9570 \\
\end{array}$ & $\begin{array}{l}0,0023 \\
0,0123 \\
0,7950 \\
\end{array}$ & $\begin{array}{l}0,0008 \\
0,0089 \\
0,3030 \\
\end{array}$ & $\begin{array}{l}0,0047 \\
0,0244 \\
1,6250 * \\
\end{array}$ & $\begin{array}{r}-0,0025 \\
0,0321 \\
-0,8510 \\
\end{array}$ \\
\hline return 15.00 & $\begin{array}{l}\text { Mean } \\
\text { Std Dev } \\
t \text {-value }\end{array}$ & $\begin{array}{l}0,0003 \\
0,0181 \\
0,0980 \\
\end{array}$ & $\begin{array}{r}-0,0043 \\
0,0221 \\
-1,4550 \\
\end{array}$ & $\begin{array}{r}-0,0009 \\
0,0106 \\
-0,2970\end{array}$ & $\begin{array}{r}-0,0027 \\
0,0171 \\
-0,9160 \\
\end{array}$ & $\begin{array}{l}0,0047 \\
0,0302 \\
1,5720\end{array}$ \\
\hline return 15.30 & $\begin{array}{l}\text { Mean } \\
\text { Std Dev } \\
t \text {-value }\end{array}$ & $\begin{array}{r}-0,0019 \\
0,0157 \\
-0,4240 \\
\end{array}$ & $\begin{array}{r}-0,0011 \\
0,0304 \\
-0,2360 \\
\end{array}$ & $\begin{array}{r}-0,0015 \\
0,0106 \\
-0,3430 \\
\end{array}$ & $\begin{array}{l}0,0008 \\
0,0162 \\
0,1740\end{array}$ & $\begin{array}{c}-0,0078 \\
0,0600 \\
-1,6790 *\end{array}$ \\
\hline return 16.00 & $\begin{array}{l}\text { Mean } \\
\text { Std Dev } \\
t \text {-value }\end{array}$ & $\begin{array}{l}0,0079 \\
0,0134 \\
3,3500 \text { * * * }{ }^{2}\end{array}$ & 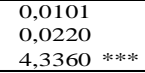 & $\begin{array}{l}0,0057 \\
0,0129 \\
2,5030 * * *\end{array}$ & $\begin{array}{l}0,0040 \\
0,0148 \\
1,6930 *\end{array}$ & 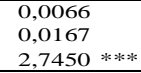 \\
\hline
\end{tabular}


Lanjutan Tabel 4

\begin{tabular}{|c|c|c|c|c|c|c|}
\hline \begin{tabular}{|l} 
Terbesar \\
\end{tabular} & & Senin & Selasa & Rabu & Kamis & Jumat \\
\hline \multirow[t]{3}{*}{ return 09.30} & Mean & $-0,0026$ & $-0,0024$ & $-0,0004$ & 0,0003 & $-0,0010$ \\
\hline & Std Dev & 0,0070 & 0,0086 & 0,0082 & 0,0102 & 0,0078 \\
\hline & $t$-value & $-2,1450 * *$ & $-1,9810 * *$ & $-0,3050$ & 0,2810 & $-0,8140$ \\
\hline \multirow[t]{3}{*}{ return 10.00} & Mean & $-0,0001$ & 0,0012 & 0,0004 & 0,0003 & 0,0017 \\
\hline & Std Dev & 0,0082 & 0,0059 & 0,0074 & 0,0056 & 0,0062 \\
\hline & $t$-value & $-0,0870$ & 1,2740 & 0,3840 & 0,3320 & $1,7440 *$ \\
\hline \multirow[t]{3}{*}{ return 10.30} & Mean & $-0,0007$ & $-0,0008$ & 0,0002 & $-0,0029$ & 0,0008 \\
\hline & Std Dev & 0,0053 & 0,0081 & 0,0057 & 0,0155 & 0,0068 \\
\hline & $t$-value & $-0,5350$ & $-0,6370$ & 0,1770 & $-2,2310 * *$ & 0,6020 \\
\hline \multirow[t]{3}{*}{ return 11.00} & Mean & $-0,0001$ & $-0,0022$ & 0,0007 & 0,0041 & $-0,0015$ \\
\hline & Std Dev & 0,0048 & 0,0264 & 0,0074 & 0,0175 & 0,0083 \\
\hline & $t$-value & $-0,0290$ & $-1,0120$ & 0,3180 & $1,8570 *$ & $-0,6810$ \\
\hline \multirow[t]{3}{*}{ return 11.30} & Mean & 0,0008 & 0,0037 & $-0,0017$ & 0,0005 & 0,0014 \\
\hline & Std Dev & 0,0040 & 0,0255 & 0,0082 & 0,0052 & 0,0057 \\
\hline & $t$-value & 0,4370 & $2,0300 * *$ & $-0,9750$ & 0,2740 & 0,7320 \\
\hline \multirow[t]{3}{*}{ return 12.00} & Mean & 0,0008 & 0,0007 & 0,0018 & 0,0007 & \\
\hline & Std Dev & 0,0068 & 0,0069 & 0,0077 & 0,0045 & \\
\hline & $t$-value & 0,8220 & 0,7590 & $1,9780 * *$ & 0,7050 & \\
\hline \multirow[t]{3}{*}{ return 13.30} & Mean & $-0,0001$ & $-0,0015$ & 0,0004 & $-0,0005$ & \\
\hline & Std Dev & 0,0034 & 0,0056 & 0,0039 & 0,0052 & \\
\hline & $t$-value & $-0,1290$ & $-2,3370 * *$ & 0,5630 & $-0,7410$ & \\
\hline \multirow[t]{3}{*}{ return 14.00} & Mean & $-0,0015$ & $-0,0014$ & $-0,0012$ & 0,0016 & $-0,0003$ \\
\hline & Std Dev & 0,0046 & 0,0060 & 0,0095 & 0,0096 & 0,0038 \\
\hline & $t$-value & $-1,4630$ & $-1,3490$ & $-1,2360$ & 1,5660 & $-0,2630$ \\
\hline \multirow[t]{3}{*}{ return 14.30} & Mean & $-0,0047$ & 0,0017 & 0,0011 & $-0,0026$ & $-0,0027$ \\
\hline & Std Dev & 0,0302 & 0,0092 & 0,0180 & 0,0128 & 0,0169 \\
\hline & $t$-value & $-1,7250 *$ & 0,6190 & 0,4050 & $-0,9740$ & $-0,9810$ \\
\hline \multirow[t]{3}{*}{ return 15.00} & Mean & 0,0002 & $-0,0006$ & 0,0005 & $-0,0013$ & $-0,0002$ \\
\hline & Std Dev & 0,0347 & 0,0051 & 0,0145 & 0,0158 & 0,0052 \\
\hline & t-value & 0,0810 & $-0,2440$ & 0,2060 & $-0,4810$ & $-0,0850$ \\
\hline \multirow[t]{3}{*}{ return 15.30} & Mean & 0,0049 & $-0,0001$ & $-0,0015$ & 0,0002 & 0,0002 \\
\hline & Std Dev & 0,0302 & 0,0088 & 0,0094 & 0,0192 & 0,0109 \\
\hline & t-value & $1,9200 *$ & $-0,0290$ & $-0,6210$ & 0,0900 & 0,0670 \\
\hline \multirow[t]{3}{*}{ return 16.00} & Mean & 0,0026 & 0,0027 & 0,0059 & 0,0058 & 0,0028 \\
\hline & Std Dev & 0,0122 & 0,0133 & 0,0113 & 0,0147 & 0,0105 \\
\hline & t-value & 1,4440 & 1,4960 & $3,3970 * * *$ & $3,2100 * * *$ & 1,5490 \\
\hline
\end{tabular}

\section{Keterangan:}

* *signifikan pada level 10,00\%; **signifikan pada level 5,00\%; ***signifika n pada level $1,00 \%$

* B, C dan D menunjukkan ukuran perusahaan yang di antara Portofolio Terkecil dan Terbesar

Gibbons \& Hess (1981) menyatakan bahwa day of the week berhubungan erat dengan ukuran perusahaan. Perusahaan dalam ukuran besar cenderung tidak terpengaruh day of the week, sedangkan perusahaan kecil cenderung untuk terpengaruh. Untuk menguji hubungan day of the week dengan ukuran perusahaan ini dibentuk ukuran perusahaan quintile portofolio. Dalam penelitian ini ukuran perusahaan diproksikan dengan besaran nilai kapitalisasi pasar. Tabel 4 menunjukkan rata-rata retum per periode dan nilai-t untuk kelima portofolio ukuran perusahaan pada kelima hari perdagangan.

Tabel 4 menunjukkan bahwa secara umum retum dipengaruhi oleh hari perdagangan. Hasil uji ini tetap mengindikasikan bahwa fenomena day of the week teta $\mathrm{p}$ terbukti valid dalam berbagai ukuran perusahaan. Simpulan atas hasil analisis ini mendukung kembali terhadap day of the week. Hanya saja, hari yang 
berpengaruh terhadap retum tidak sama, a ta u dengan kata la in fenomena day of the week ini tidaklah konsisten harinya. Hari Senin, Selasa, Rabu, Kamis dan Jum'at secara bergantian mempengaruhi retum. Demikian juga, hasil uji penelitian ini menunjukkan bahwa retum pada hari Senin dalam bandingannya dengan retum hari-hari yang lainnya tidak selalu terbukti memiliki retum negatif yang eksesif. Artinya fenomena Monday effect tidak persisten terja di di Bursa Efek J akarta. Secara umum Monday Effect terjadi pada penusahaan-perusahaan besar pada awal-awal perdagangan.

\section{Pengendalian dengan Basis Volume Perdagangan}

Volume perdagangan memberikan indikasi terjadi pergerakan harga. Tingkat volume yang tinggi mengindikasikan bahwa harga saham cendenung bergeser ke harga yang lebih tinggi. Sebaliknya, tingkat volume perdagangan yang rendah mengindikasikan harga berpindah ke tingkat harga yang lebih rendah. Kecenderungan ini dipenga ruhi oleh ekspekta si para pela ku saham untuk bertindak ataupun tidak bertindak untuk bertransaksi. Selanjutnya, volume transaksi perdagangan ini berkaitan dengan retum (Easly \& O'Hara, 1997). Sehingga, retum saham baik terkendali secara sistematis oleh adanya volume tamsaksi perdagangan yang terjadi.

Volume transaksi perdagangan berhubungan dengan kedatangan informasi. Kedatangan informasi mengakibatkan permintaan untuk beli lebih banyak ketimbang transaksi untuk jual. Kondisi yang demikian ini mengakibatkan meningkatnya volume transaksi perdagangan. Saat volume tansaksi perdagangan tinggi terjadilah variansi retum yang meningkat pula. Sebaliknya, ketika volume transaksi perdagangan melemah maka variansi retum ikut berkurang (Karpoff 1987, serta Admati \& Pflederer 1988). Oleh karena itu, dengan menggunakan silogisma yang yang sama, maka day of the week juga dapat dikendalikan dengan basis volume perdagangan.

Tabel 5 menjelaskan rata-rata retum dan nilai-t yang dikenda likan dengan besaran volume perdagangan untuk kelima portofolio. Hasil uji ini tmengindikasikan bahwa secara umum fenomena day of the week tetap terbukti valid dalam berbagai volume perdagangan, kecuali untuk portofolio perusahaan dengan volume perdagangan terkecil, dimana day of the week hanya terjadi pada periode 11.00 , 13.30 dan 15.00. Hasil ini menupakan kebalikan dengan penelitian yang dilakukan oleh Gibbon \& Hess (1981). Hari yang berpengaruh terhadap retum juga tidak selalu sama, atau dengan kata la in fenomena day of the week ini tidaklah konsisten harinya. Selain itu hasil uji menunjukkan bahwa retum pada hari Senin dalam bandingannya dengan hari-hari yang la innya tidak selalu terbukti memiliki retum negatif yang eksesif. Monday Effect terjadi pada volume perdagangan terbesar pada awal perdagangan dan akhir perdagangan. 
Tabel 5

Ha sil Uji Day of the Week yang Dikendalikan dengan Volume Perdagangan

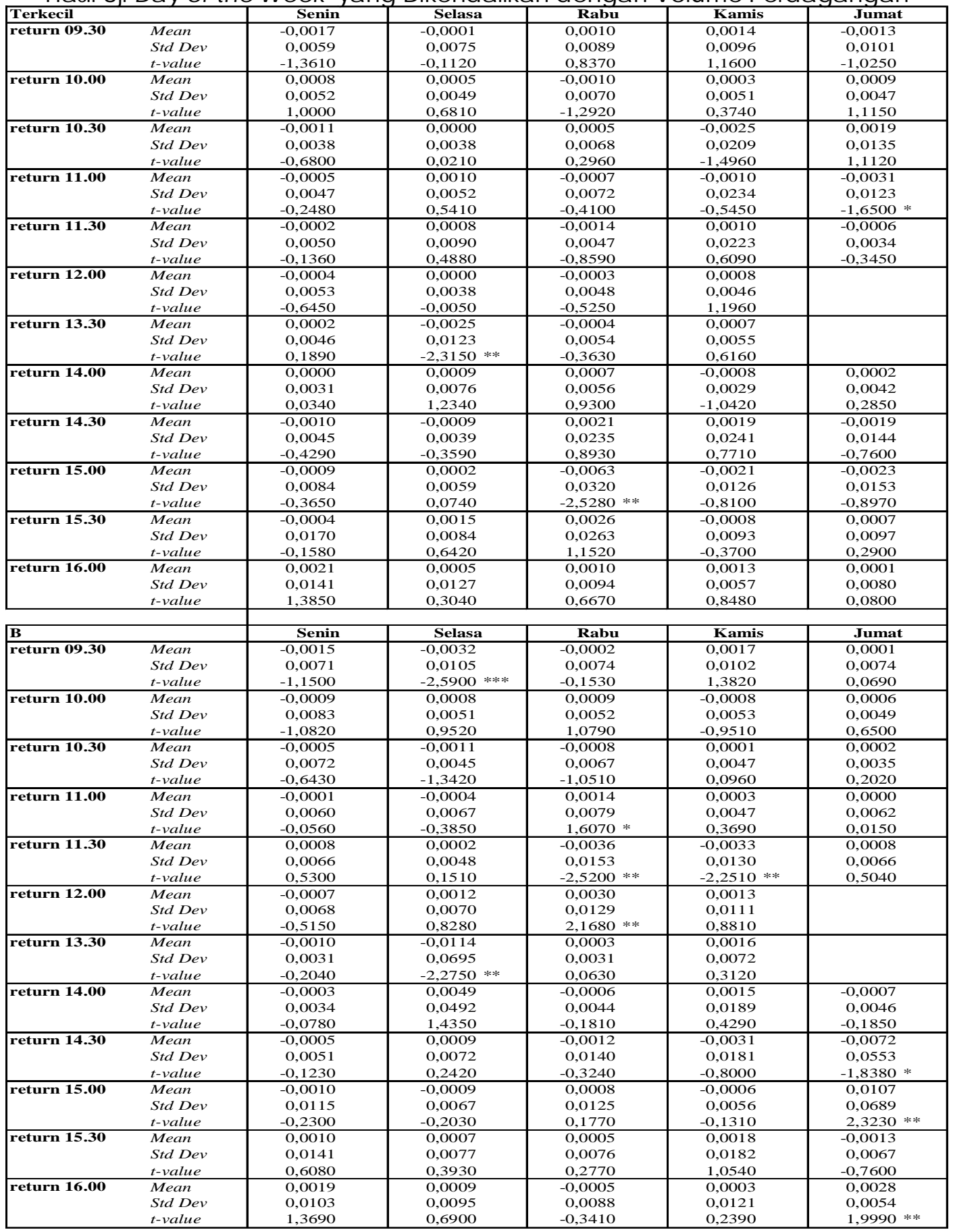


Lanjutan Tabel

\begin{tabular}{|c|c|c|c|c|c|c|}
\hline \multirow{2}{*}{\begin{tabular}{|l|} 
C \\
return 09.30
\end{tabular}} & & Senin & Selasa & Rabu & Kamis & Jumat \\
\hline & $\begin{array}{l}\text { Mean } \\
\text { Std Dev } \\
\text { t-value }\end{array}$ & $\begin{array}{r}-0,0014 \\
0,0064 \\
-0,8530\end{array}$ & $\begin{array}{r}-0,0009 \\
0,0082 \\
-0,5680\end{array}$ & $\begin{array}{r}-0,0003 \\
0,0080 \\
-0,2050\end{array}$ & $\begin{array}{l}0,0019 \\
0,0117 \\
1,1530\end{array}$ & $\begin{array}{r}-0,0026 \\
0,0187 \\
-1,5810\end{array}$ \\
\hline return 10.00 & $\begin{array}{l}\text { Mean } \\
\text { Std Dev } \\
t \text {-value }\end{array}$ & $\begin{array}{r}-0,0011 \\
0,0090 \\
-1,1500\end{array}$ & $\begin{array}{l}0,0001 \\
0,0053 \\
0,0960\end{array}$ & $\begin{array}{l}0,0013 \\
0,0056 \\
1,4900\end{array}$ & $\begin{array}{r}-0,0007 \\
0,0059 \\
-0,7370\end{array}$ & $\begin{array}{l}0,0010 \\
0,0052 \\
1,0320\end{array}$ \\
\hline return 10.30 & $\begin{array}{l}\text { Mean } \\
\text { Std Dev } \\
t \text {-value }\end{array}$ & $\begin{array}{r}-0,0030 \\
0,0201 \\
-1,6010\end{array}$ & $\begin{array}{r}-0,0012 \\
0,0069 \\
-0,6300\end{array}$ & $\begin{array}{r}0,0000 \\
0,0042 \\
-0,0220 \\
\end{array}$ & $\begin{array}{r}-0,0022 \\
0,0184 \\
-1,2160\end{array}$ & $\begin{array}{r}-0,0003 \\
0,0040 \\
-0,1340\end{array}$ \\
\hline return 11.00 & $\begin{array}{l}\text { Mean } \\
\text { Std Dev } \\
\text { t-value }\end{array}$ & $\begin{array}{l}0,0020 \\
0,0246 \\
0,8640\end{array}$ & $\begin{array}{l}0,0012 \\
0,0082 \\
0,5190\end{array}$ & $\begin{array}{r}-0,0013 \\
0,0077 \\
-0,5830\end{array}$ & $\begin{array}{l}0,0027 \\
0,0221 \\
1,1770\end{array}$ & $\begin{array}{l}0,0010 \\
0,0062 \\
0,4270\end{array}$ \\
\hline return 11.30 & $\begin{array}{l}\text { Mean } \\
\text { Std Dev } \\
t \text {-value }\end{array}$ & $\begin{array}{r}-0,0005 \\
0,0072 \\
-0,1650\end{array}$ & $\begin{array}{r}-0,0003 \\
0,0071 \\
-0,1060 \\
\end{array}$ & $\begin{array}{r}-0,0041 \\
0,0465 \\
-1,3250\end{array}$ & $\begin{array}{r}-0,0003 \\
0,0083 \\
-0,0820 \\
\end{array}$ & $\begin{array}{r}-0,0006 \\
0,0056 \\
-0,1940 \\
\end{array}$ \\
\hline return 12.00 & $\begin{array}{l}\text { Mean } \\
\text { Std Dev } \\
t \text {-value }\end{array}$ & $\begin{array}{l}0,0018 \\
0,0101 \\
0,5840\end{array}$ & $\begin{array}{l}0,0000 \\
0,0042 \\
0,0100\end{array}$ & $\begin{array}{l}0,0047 \\
0,0388 \\
1,5980\end{array}$ & $\begin{array}{r}-0,0001 \\
0,0070 \\
-0,0280 \\
\end{array}$ & \\
\hline return 13.30 & $\begin{array}{l}\text { Mean } \\
\text { Std Dev } \\
\text { t-value }\end{array}$ & $\begin{array}{r}-0,0007 \\
0,0063 \\
-1,1010\end{array}$ & $\begin{array}{c}-0,0010 \\
0,0034 \\
-1,6350 *\end{array}$ & $\begin{array}{r}-0,0007 \\
0,0031 \\
-1,0770\end{array}$ & $\begin{array}{l}0,0000 \\
0,0039 \\
0,0760\end{array}$ & \\
\hline return 14.00 & $\begin{array}{l}\text { Mean } \\
\text { Std Dev } \\
t \text {-value }\end{array}$ & $\begin{array}{c}-0,0016 \\
0,0060 \\
-1,6950 * \\
\end{array}$ & $\begin{array}{r}-0,0010 \\
0,0047 \\
-1,0680 \\
\end{array}$ & $\begin{array}{r}-0,0006 \\
0,0059 \\
-0,6170 \\
\end{array}$ & $\begin{array}{r}-0,0015 \\
0,0088 \\
-1,5460 \\
\end{array}$ & $\begin{array}{l}0,0004 \\
0,0067 \\
0,3970 \\
\end{array}$ \\
\hline return 14.30 & $\begin{array}{l}\text { Mean } \\
\text { Std Dev } \\
t \text {-value }\end{array}$ & $\begin{array}{r}-0,0064 \\
0,0376 \\
-2,4610 \text { ** }\end{array}$ & $\begin{array}{l}0,0018 \\
0,0083 \\
0,7060 \\
\end{array}$ & $\begin{array}{l}0,0015 \\
0,0070 \\
0,6060 \\
\end{array}$ & $\begin{array}{r}-0,0006 \\
0,0057 \\
-0,2480 \\
\end{array}$ & $\begin{array}{r}-0,0018 \\
0,0072 \\
-0,6790 \\
\end{array}$ \\
\hline return 15.00 & $\begin{array}{l}\text { Mean } \\
\text { Std Dev } \\
t \text {-value }\end{array}$ & $\begin{array}{l}0,0050 \\
0,0405 \\
1,3600\end{array}$ & $\begin{array}{r}-0,0056 \\
0,0322 \\
-1,5430 \\
\end{array}$ & $\begin{array}{r}-0,0041 \\
0,0179 \\
-1,1650\end{array}$ & $\begin{array}{r}-0,0022 \\
0,0123 \\
-0,6080 \\
\end{array}$ & $\begin{array}{l}0,0004 \\
0,0057 \\
0,1140 \\
\end{array}$ \\
\hline return 15.30 & $\begin{array}{l}\text { Mean } \\
\text { Std Dev } \\
\text { t-value } \\
\text { Mean }\end{array}$ & $\begin{array}{l}0,0019 \\
0,0184 \\
0,6040 \\
0,0023\end{array}$ & $\begin{array}{l}0,0047 \\
0,0329 \\
1,5190 \\
0,0030\end{array}$ & $\begin{array}{l}0,0024 \\
0,0169 \\
0,7860 \\
0,0036\end{array}$ & $\begin{array}{l}0,0012 \\
0,0136 \\
0,3850 \\
0,0022 \\
\end{array}$ & $\begin{array}{l}0,0007 \\
0,0212 \\
0,2110 \\
0,0016 \\
\end{array}$ \\
\hline return 16.00 & $\begin{array}{l}\text { Std Dev } \\
\text { t-value }\end{array}$ & $\begin{array}{l}0,0081 \\
1,3130 \\
\end{array}$ & $\begin{array}{l}0,0097 \\
1,7170 *\end{array}$ & $\begin{array}{l}0,0080 \\
2,1030 * *\end{array}$ & $\begin{array}{l}0,0090 \\
1,2500 \\
\end{array}$ & $\begin{array}{l}0,0218 \\
0,9010 \\
\end{array}$ \\
\hline \multicolumn{2}{|l|}{$\mathbf{D}$} & Senin & Selasa & Rabu & Kamis & Jumat \\
\hline return 09.30 & $\begin{array}{l}\text { Mean } \\
\text { Std Dev } \\
t \text {-value }\end{array}$ & $\begin{array}{r}-0,0025 \\
0,0067 \\
-1,7840 * \\
\end{array}$ & $\begin{array}{r}-0,0009 \\
0,0064 \\
-0,6430 \\
\end{array}$ & $\begin{array}{l}0,0002 \\
0,0073 \\
0,1170 \\
\end{array}$ & $\begin{array}{l}0,0014 \\
0,0102 \\
1,0240\end{array}$ & $\begin{array}{r}-0,0018 \\
0,0149 \\
-1,2800 \\
\end{array}$ \\
\hline return 10.00 & $\begin{array}{l}\text { Mean } \\
\text { Std Dev } \\
t \text {-value }\end{array}$ & $\begin{array}{l}0,0027 \\
0,0063 \\
2,8960 \text { 水水 }\end{array}$ & $\begin{array}{l}0,0013 \\
0,0074 \\
1,4170 \\
\end{array}$ & $\begin{array}{l}0,0006 \\
0,0056 \\
0,6340 \\
\end{array}$ & $\begin{array}{r}-0,0014 \\
0,0058 \\
-1,4760 \\
\end{array}$ & $\begin{array}{l}0,0017 \\
0,0071 \\
1,8200 *\end{array}$ \\
\hline return 10.30 & $\begin{array}{l}\text { Mean } \\
\text { Std Dev } \\
t \text {-value }\end{array}$ & $\begin{array}{r}-0,0013 \\
0,0043 \\
-1,0630 \\
\end{array}$ & $\begin{array}{r}-0,0008 \\
0,0064 \\
-0,6890 \\
\end{array}$ & $\begin{array}{l}0,0001 \\
0,0042 \\
0,1190 \\
\end{array}$ & $\begin{array}{r}-0,0018 \\
0,0154 \\
-1,5370 \\
\end{array}$ & $\begin{array}{l}0,0006 \\
0,0052 \\
0,4590 \\
\end{array}$ \\
\hline return 11.00 & $\begin{array}{l}\text { Mean } \\
\text { Std Dev } \\
t \text {-value }\end{array}$ & $\begin{array}{l}0,0000 \\
0,0036 \\
0,0090\end{array}$ & $\begin{array}{r}-0,0008 \\
0,0158 \\
-0,4630\end{array}$ & $\begin{array}{l}0,0003 \\
0,0051 \\
0,1600\end{array}$ & $\begin{array}{l}0,0013 \\
0,0194 \\
0,7840\end{array}$ & $\begin{array}{r}-0,0002 \\
0,0045 \\
-0,1130\end{array}$ \\
\hline return 11.30 & $\begin{array}{l}\text { Mean } \\
\text { Std Dev } \\
t \text {-value }\end{array}$ & $\begin{array}{l}0,0013 \\
0,0043 \\
1,0270 \\
\end{array}$ & $\begin{array}{l}0,0018 \\
0,0150 \\
1,4130 \\
\end{array}$ & $\begin{array}{r}-0,0008 \\
0,0034 \\
-0,6070 \\
\end{array}$ & $\begin{array}{l}0,0004 \\
0,0117 \\
0,3170 \\
\end{array}$ & $\begin{array}{l}0,0002 \\
0,0045 \\
0,1630 \\
\end{array}$ \\
\hline return 12.00 & $\begin{array}{l}\text { Mean } \\
\text { Std Dev } \\
t \text {-value }\end{array}$ & $\begin{array}{r}-0,0004 \\
0,0042 \\
-0,4580 \\
\end{array}$ & $\begin{array}{r}-0,0012 \\
0,0102 \\
-1,2250 \\
\end{array}$ & $\begin{array}{r}-0,0006 \\
0,0045 \\
-0,6250 \\
\end{array}$ & $\begin{array}{l}0,0005 \\
0,0065 \\
0,5390 \\
\end{array}$ & \\
\hline return 13.30 & $\begin{array}{l}\text { Mean } \\
\text { Std Dev } \\
t \text {-value }\end{array}$ & $\begin{array}{r}0,0000 \\
0,0020 \\
-0,0400 \\
\end{array}$ & $\begin{array}{l}0,0004 \\
0,0098 \\
0,4250 \\
\end{array}$ & $\begin{array}{r}-0,0015 \\
0,0104 \\
-1,4130 \\
\end{array}$ & $\begin{array}{r}0,0000 \\
0,0027 \\
-0,0380 \\
\end{array}$ & \\
\hline return 14.00 & $\begin{array}{l}\text { Mean } \\
\text { Std Dev } \\
t \text {-value } \\
\end{array}$ & $\begin{array}{r}-0,0001 \\
0,0038 \\
-0,1340 \\
\end{array}$ & $\begin{array}{r}-0,0018 \\
0,0056 \\
-2,0770 * * \\
\end{array}$ & $\begin{array}{l}0,0006 \\
0,0102 \\
0,7100 \\
\end{array}$ & $\begin{array}{r}-0,0002 \\
0,0039 \\
-0,1980 \\
\end{array}$ & $\begin{array}{l}0,0001 \\
0,0033 \\
0,1130 \\
\end{array}$ \\
\hline return 14.30 & $\begin{array}{l}\text { Mean } \\
\text { Std Dev } \\
t \text {-value }\end{array}$ & $\begin{array}{r}-0,0009 \\
0,0049 \\
-0,9700 \\
\end{array}$ & $\begin{array}{l}0,0013 \\
0,0086 \\
1,4290 \\
\end{array}$ & $\begin{array}{l}0,0010 \\
0,0081 \\
1,1360 \\
\end{array}$ & $\begin{array}{r}-0,0006 \\
0,0049 \\
-0,6640 \\
\end{array}$ & $\begin{array}{r}-0,0009 \\
0,0044 \\
-0,9220 \\
\end{array}$ \\
\hline return 15.00 & $\begin{array}{l}\text { Mean } \\
\text { Std Dev } \\
t \text {-value } \\
\end{array}$ & $\begin{array}{r}-0,0014 \\
0,0090 \\
-1,3530 \\
\end{array}$ & $\begin{array}{r}-0,0011 \\
0,0065 \\
-1,0750 \\
\end{array}$ & $\begin{array}{r}-0,0002 \\
0,0082 \\
-0,2150 \\
\end{array}$ & $\begin{array}{r}-0,0007 \\
0,0074 \\
-0,6430 \\
\end{array}$ & $\begin{array}{l}0,0004 \\
0,0045 \\
0,3450 \\
\end{array}$ \\
\hline \begin{tabular}{|l|} 
return 15.30 \\
\end{tabular} & $\begin{array}{l}\text { Mean } \\
\text { Std Dev } \\
t \text {-value }\end{array}$ & $\begin{array}{l}0,0007 \\
0,0094 \\
0,4290 \\
\end{array}$ & $\begin{array}{r}-0,0018 \\
0,0150 \\
-1,1840 \\
\end{array}$ & $\begin{array}{l}0,0000 \\
0,0089 \\
0,0290 \\
\end{array}$ & $\begin{array}{r}-0,0010 \\
0,0108 \\
-0,6630 \\
\end{array}$ & $\begin{array}{r}-0,0012 \\
0,0062 \\
-0,7800 \\
\end{array}$ \\
\hline return 16.00 & $\begin{array}{l}\text { Mean } \\
\text { Std Dev } \\
t \text {-value }\end{array}$ & $\begin{array}{l}0,0041 \\
0,0073 \\
2,8150 \text { **** }\end{array}$ & 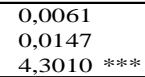 & $\begin{array}{l}0,0026 \\
0,0097 \\
1,8650 *\end{array}$ & $\begin{array}{l}0,0040 \\
0,0081 \\
2,7900 * * *\end{array}$ & $\begin{array}{l}0,0043 \\
0,0079 \\
2,9280 \text { **** }\end{array}$ \\
\hline
\end{tabular}


Lanjutan Tabel 5

\begin{tabular}{|c|c|c|c|c|c|c|}
\hline \begin{tabular}{|l} 
Terbesar \\
\end{tabular} & & Senin & Selasa & Rabu & Kamis & Jumat \\
\hline return 09.30 & $\begin{array}{l}\text { Mean } \\
\text { Std Dev } \\
t \text {-value }\end{array}$ & $\begin{array}{r}-0,0048 \\
0,0089 \\
-3,3760 * * *\end{array}$ & $\begin{array}{r}-0,0038 \\
0,0081 \\
-2,7380 * * *\end{array}$ & $\begin{array}{r}-0,0028 \\
0,0090 \\
-2,0620 * *\end{array}$ & $\begin{array}{r}-0,0006 \\
0,0117 \\
-0,4230\end{array}$ & $\begin{array}{c}-0,0028 \\
0,0103 \\
-1,9600 *\end{array}$ \\
\hline return 10.00 & $\begin{array}{l}\text { Mean } \\
\text { Std Dev } \\
t \text {-value }\end{array}$ & $\begin{array}{r}-0,0003 \\
0,0118 \\
-0,2140\end{array}$ & $\begin{array}{l}0,0003 \\
0,0075 \\
0,2210\end{array}$ & $\begin{array}{l}0,0005 \\
0,0078 \\
0,3720\end{array}$ & $\begin{array}{l}0,0009 \\
0,0078 \\
0,6080\end{array}$ & $\begin{array}{l}0,0019 \\
0,0130 \\
1,3270\end{array}$ \\
\hline return 10.30 & $\begin{array}{l}\text { Mean } \\
\text { Std Dev } \\
t \text {-value }\end{array}$ & $\begin{array}{r}-0,0002 \\
0,0076 \\
-0,1560 \\
\end{array}$ & $\begin{array}{r}-0,0011 \\
0,0088 \\
-0,7040 \\
\end{array}$ & $\begin{array}{l}0,0008 \\
0,0058 \\
0,5190 \\
\end{array}$ & $\begin{array}{r}-0,0024 \\
0,0161 \\
-1,5440 \\
\end{array}$ & $\begin{array}{l}0,0007 \\
0,0127 \\
0,4470 \\
\end{array}$ \\
\hline return 11.00 & $\begin{array}{l}\text { Mean } \\
\text { Std Dev } \\
t \text {-value }\end{array}$ & $\begin{array}{r}-0,0015 \\
0,0067 \\
-0,5600\end{array}$ & $\begin{array}{l}0,0017 \\
0,0128 \\
0,6650\end{array}$ & $\begin{array}{l}0,0006 \\
0,0056 \\
0,2510\end{array}$ & $\begin{array}{l}0,0035 \\
0,0183 \\
1,3640\end{array}$ & $\begin{array}{r}-0,0031 \\
0,0329 \\
-1,1590\end{array}$ \\
\hline return 11.30 & $\begin{array}{l}\text { Mean } \\
\text { Std Dev } \\
t \text {-value }\end{array}$ & $\begin{array}{l}0,0001 \\
0,0099 \\
0,0410\end{array}$ & $\begin{array}{r}-0,0013 \\
0,0121 \\
-0,3670 \\
\end{array}$ & $\begin{array}{r}-0,0018 \\
0,0233 \\
-0,5130\end{array}$ & $\begin{array}{l}0,0007 \\
0,0099 \\
0,1940\end{array}$ & $\begin{array}{l}0,0094 \\
0,0470 \\
2,5840 * * *\end{array}$ \\
\hline return 12.00 & $\begin{array}{l}\text { Mean } \\
\text { Std Dev } \\
t \text {-value }\end{array}$ & $\begin{array}{r}-0,0005 \\
0,0109 \\
-0,3980 \\
\end{array}$ & $\begin{array}{l}0,0030 \\
0,0082 \\
2,4800 * *\end{array}$ & $\begin{array}{l}0,0000 \\
0,0079 \\
0,0100 \\
\end{array}$ & $\begin{array}{l}0,0001 \\
0,0067 \\
0,0670 \\
\end{array}$ & \\
\hline return 13.30 & $\begin{array}{l}\text { Mean } \\
\text { Std Dev } \\
t \text {-value }\end{array}$ & $\begin{array}{r}-0,0008 \\
0,0044 \\
-0,8880 \\
\end{array}$ & $\begin{array}{r}-0,0026 \\
0,0090 \\
-3,0330 * * *\end{array}$ & $\begin{array}{l}0,0001 \\
0,0044 \\
0,1000 \\
\end{array}$ & $\begin{array}{l}0,0012 \\
0,0053 \\
1,3570 \\
\end{array}$ & \\
\hline return 14.00 & $\begin{array}{l}\text { Mean } \\
\text { Std Dev } \\
t \text {-value }\end{array}$ & $\begin{array}{r}-0,0009 \\
0,0057 \\
-0,6460\end{array}$ & $\begin{array}{r}-0,0002 \\
0,0105 \\
-0,1350\end{array}$ & $\begin{array}{r}-0,0004 \\
0,0079 \\
-0,3160\end{array}$ & $\begin{array}{r}-0,0005 \\
0,0115 \\
-0,3890\end{array}$ & $\begin{array}{r}-0,0005 \\
0,0091 \\
-0,3460 \\
\end{array}$ \\
\hline return 14.30 & $\begin{array}{l}\text { Mean } \\
\text { Std Dev } \\
t \text {-value }\end{array}$ & $\begin{array}{r}-0,0017 \\
0,0087 \\
-1,0940\end{array}$ & $\begin{array}{l}0,0020 \\
0,0112 \\
1,2660\end{array}$ & $\begin{array}{l}0,0013 \\
0,0074 \\
0,8280\end{array}$ & $\begin{array}{l}0,0028 \\
0,0164 \\
1,7940 *\end{array}$ & $\begin{array}{l}0,0026 \\
0,0078 \\
1,6570 *\end{array}$ \\
\hline return 15.00 & $\begin{array}{l}\text { Mean } \\
\text { Std Dev } \\
t \text {-value }\end{array}$ & $\begin{array}{r}-0,0027 \\
0,0197 \\
-1,6830 *\end{array}$ & $\begin{array}{r}-0,0007 \\
0,0084 \\
-0,4350\end{array}$ & $\begin{array}{l}0,0004 \\
0,0051 \\
0,2360\end{array}$ & $\begin{array}{r}-0,0001 \\
0,0083 \\
-0,0710\end{array}$ & $\begin{array}{l}0,0004 \\
0,0076 \\
0,2190\end{array}$ \\
\hline return 15.30 & $\begin{array}{l}\text { Mean } \\
\text { Std Dev } \\
t \text {-value }\end{array}$ & $\begin{array}{r}-0,0003 \\
0,0225 \\
-0,1140 \\
\end{array}$ & $\begin{array}{r}-0,0066 \\
0,0295 \\
-2,3360 \text { ** } \\
\end{array}$ & $\begin{array}{r}-0,0042 \\
0,0127 \\
-1,5080 \\
\end{array}$ & $\begin{array}{r}-0,0024 \\
0,0144 \\
-0,8300 \\
\end{array}$ & $\begin{array}{r}-0,0020 \\
0,0147 \\
-0,6890 \\
\end{array}$ \\
\hline return 16.00 & $\begin{array}{l}\text { Mean } \\
\text { Std Dev } \\
t \text {-value }\end{array}$ & $\begin{array}{l}0,0098 \\
0,0144 \\
3,9550 \text { **** }\end{array}$ & $\begin{array}{l}0,0141 \\
0,0263 \\
5,7230 * * *\end{array}$ & $\begin{array}{l}0,0135 \\
0,0130 \\
5,5900 * * *\end{array}$ & $\begin{array}{l}0,0107 \\
0,0141 \\
4,3050 * * *\end{array}$ & $\begin{array}{l}0,0121 \\
0,0148 \\
4,7670 * * * *\end{array}$ \\
\hline
\end{tabular}

\section{Keterangan:}

* *signifikan pada level 10,00\%; **signifikan pada level 5,00\%; ***signifikan pa da level 1,00\%

* B, C dan D menunjukkan besaran volume perdagangan yang di antara Portofolio Volume Perdagangan Terkecil dan Terbesar

\section{Pengendalian dengan Basis Bentang Tawar Minta}

Perdagangan saham akan berlangsung apabila terjadi harga keseimbangan antara harga penawaran dan harga permintaan. Seringkali harga penawa ran dan harga permintaan tidak sama sehingga perdagangan tidak tejadi. Hal ini membuat harga saham turun atau naik karena pembeli akan menaikkan harga dan pedagang akan membuat harga turun. Frekuensi perdagangan saham akan meningkat apabila rentang (selisih) antara harga penawaran dan pembelian tidak terlalu jauh.

Dalam hubungan antara spread dan retum saham, Amihud \& Mendelson (1986) mengemukakan bahwa semakin tinggi spread suatu aset maka akan semakin tinggi pula tingkat retum yang disyaratkan. Adanya spread yang semakin tinggi 
menandakan bahwa tingkat likuiditas dari saham tersebut semakin rendah sehingga saham tersebut relatif sulit dan jarang unutk diperdagangkan di dalam bursa efek. Likuiditas (kemampuan suatu saham untuk melakukan pembelian atau penjualan) merupakan faktor yang menjadi bahan pertimbangan dalam investasi. Semakin mudah melakukan penjualan/pembelian terhadap suatu saham, maka saham tersebut dikatakan semakin likuid. Investor lebih suka kepada saham yang likuid dibandingkan dengan saham yang tidak likuid. Kemudahan dalam melakukan transaksi saham-saham yang likuid akan menurunkan selish tawar menawar antar investor sehingga meningkatkan frekuensi perdagangan terhadap saham. Semakin likuid suatu saham memiliki selisih harga penawaran dan harga permintaan yang semakin kecil. Bentang tawar minta yang terlalu besar menandakan sa ham tersebut semakin tidak likuid.

Saham yang sering diperdagangkan memiliki risiko yang lebih kecil dibandingkan dengan saham yang jarang diperdagangkan sebagai akibat adanya informasi yang berkaitan dengan perdagangan (Easley \& O'Hara 1987). Semakin tidak aktif suatu saham semakin berisiko ka rena memiliki banyak perdagangan yang dilakukan berdasarkan informasi yang yang tejadi, misalnya informasi laporan keuangan, merger, akusisi ataupun informasi lain yang memberikan kandungan informasi kepada pasar modal tersebut. Tidak seningnya saham tersebut diperdagangkan di bursa efek mengakibatkan saham tersebut lebih berisiko terhadap pengaruh informasi yang spesifik yang terdistribusi dan masuk ke dalam pasar modal.

Semakin besar spread suatu saham, maka semakin besar tingkat retum yang diharapkan dari saham tersebut. Rata-rata risk adjusted retum portofolio meningkat sesuai dengan bid-ask spread dan slope dari hubungan retum-spread akan menurun seining dengan peningkatan spread (Amihud \& Mendelson 1986). Retum yang disyaratkan akan meningkat sesuai dengan kenaikan spread suatu aset dengan kenaikan yang semakin kecil. Oleh karena itu, ada besamya bentang tawar minta (bid ask spread) mempengaruhi perilaku harga saham tersebut, sehingga faktor bentang tawar minta ini perlu dikendalikan untuk melihat fenomena day of the week.

Tabel 6 menjelaskan rata-rata retum dan nilai-t yang dikenda likan dengan besaran bentang tawar-minta untuk kelima portofolio. Hasil uji ini mengindikasikan bahwa secara umum fenomena day of the week tetap terbukti valid dalam berbagai bentang tawar minta, tetapi hari yang berpengaruh terhadap retum juga tidak sela lu sama, a tau dengan kata la in fenomena day of the week ini tidaklah konsisten harinya. Selain itu hasil uji menunjukkan bahwa retum pada hari Senin dalam bandingannya dengan hari-hari yang lainnya tidak selalu terbukti memiliki retum nega tif yang eksesif dan berpenga ruh terhadap retum. Hal ini berarti Monday Effect terjadi hanya parsial dan insidentil saja. 
Tabel 6

Hasil Uji Day of the Week yang Dikenda likan dengan Bentang Ta war Minta

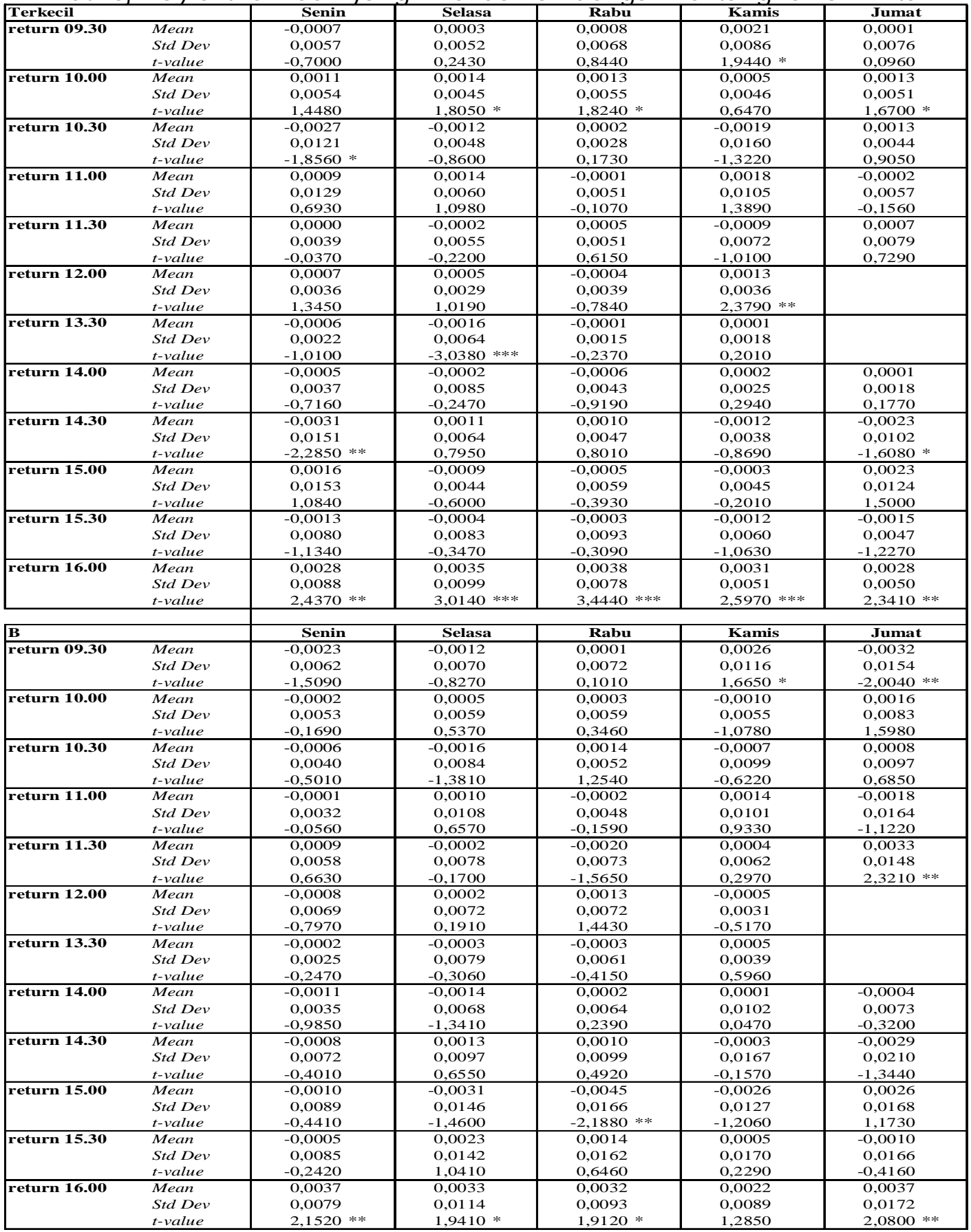


Lanjutan Tabel 6

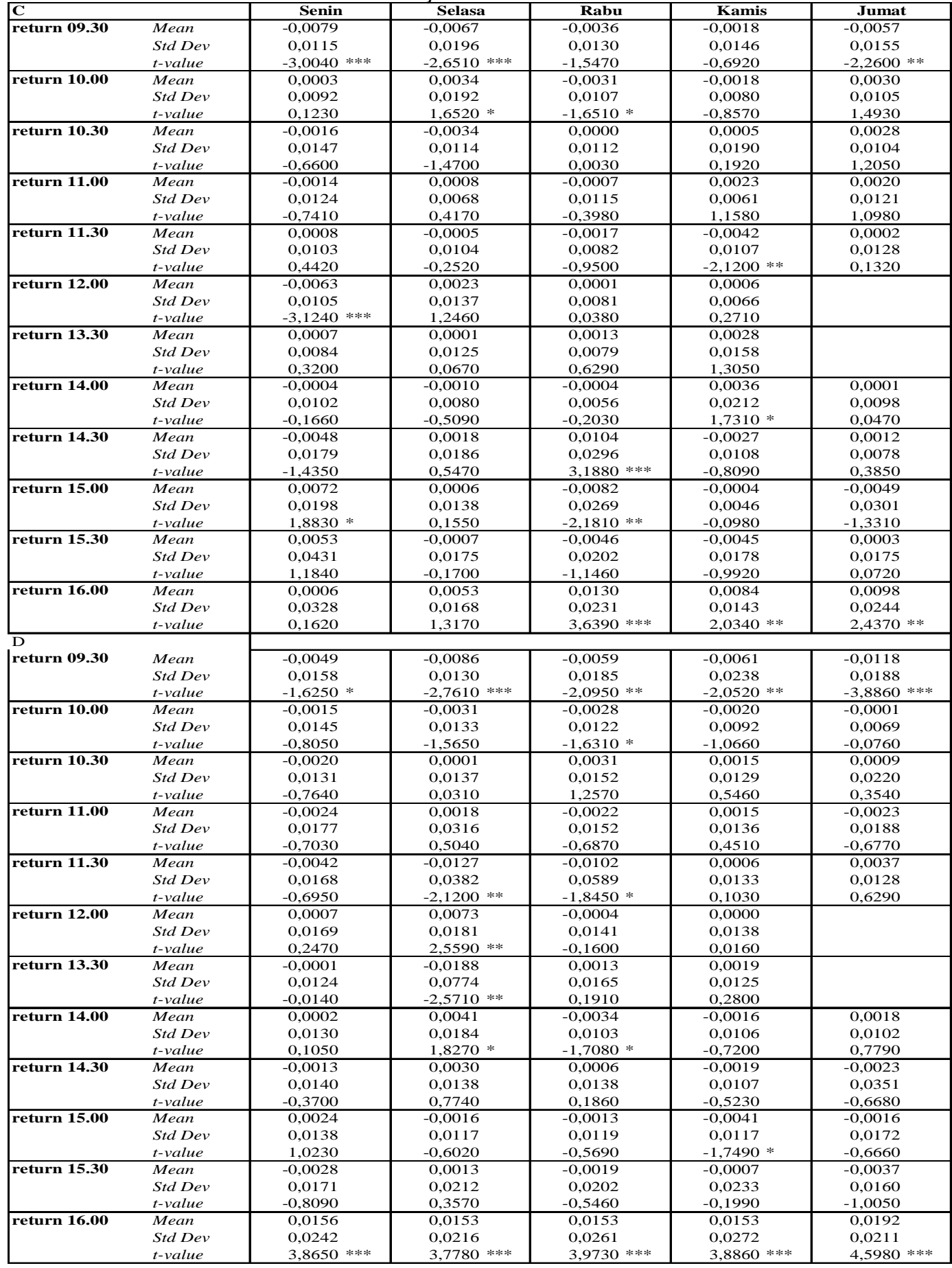


Lanjutan Tabel 6

\begin{tabular}{|c|c|c|c|c|c|c|}
\hline Terbesar & & Senin & Selasa & Rabu & Kamis & Jumat \\
\hline return 09.30 & $\begin{array}{l}\text { Mean } \\
\text { Std Dev } \\
t \text {-value }\end{array}$ & $\begin{array}{c}-0,0205 \\
0,0224 \\
-1,9670 *\end{array}$ & $\begin{array}{r}-0,0179 \\
0,0341 \\
-1,4040\end{array}$ & $\begin{array}{r}-0,0069 \\
0,0261 \\
-0,5930\end{array}$ & $\begin{array}{r}-0,0058 \\
0,0207 \\
-0,5000\end{array}$ & $\begin{array}{c}-0,0291 \\
0,0963 \\
-2,4360 * *\end{array}$ \\
\hline return 10.00 & $\begin{array}{l}\text { Mean } \\
\text { Std Dev } \\
t \text {-value }\end{array}$ & $\begin{array}{r}-0,0092 \\
0,0206 \\
-2,1230 * *\end{array}$ & $\begin{array}{l}0,0043 \\
0,0359 \\
0,7880\end{array}$ & $\begin{array}{r}-0,0011 \\
0,0116 \\
-0,2180\end{array}$ & $\begin{array}{l}0,0025 \\
0,0103 \\
0,5050\end{array}$ & $\begin{array}{r}-0,0087 \\
0,0169 \\
-1,7130 *\end{array}$ \\
\hline return 10.30 & $\begin{array}{l}\text { Mean } \\
\text { Std Dev } \\
t \text {-value }\end{array}$ & $\begin{array}{l}0,0068 \\
0,0132 \\
0,5750\end{array}$ & $\begin{array}{r}-0,0085 \\
0,0422 \\
-0,5070 \\
\end{array}$ & $\begin{array}{r}-0,0038 \\
0,0126 \\
-0,2810 \\
\end{array}$ & $\begin{array}{r}-0,0469 \\
0,1085 \\
-3,4430 * * *\end{array}$ & $\begin{array}{r}-0,0001 \\
0,0164 \\
-0,0040 \\
\end{array}$ \\
\hline return 11.00 & $\begin{array}{l}\text { Mean } \\
\text { Std Dev } \\
t \text {-value }\end{array}$ & $\begin{array}{r}-0,0075 \\
0,0226 \\
-0,5130 \\
\end{array}$ & $\begin{array}{l}0,0148 \\
0,0503 \\
0,9040 \\
\end{array}$ & $\begin{array}{r}-0,0033 \\
0,0154 \\
-0,2250 \\
\end{array}$ & $\begin{array}{l}0,0561 \\
0,1272 \\
3,2780 * * *\end{array}$ & $\begin{array}{l}0,0060 \\
0,0131 \\
0,4090 \\
\end{array}$ \\
\hline return 11.30 & $\begin{array}{l}\text { Mean } \\
\text { Std Dev } \\
t \text {-value }\end{array}$ & $\begin{array}{l}0,0028 \\
0,0177 \\
0,4400 \\
\end{array}$ & $\begin{array}{r}-0,0082 \\
0,0430 \\
-1,1550 \\
\end{array}$ & $\begin{array}{l}0,0008 \\
0,0138 \\
0,1210 \\
\end{array}$ & $\begin{array}{r}-0,0033 \\
0,0225 \\
-0,4010 \\
\end{array}$ & $\begin{array}{l}0,0057 \\
0,0184 \\
0,8000 \\
\end{array}$ \\
\hline return 12.00 & $\begin{array}{l}\text { Mean } \\
\text { Std Dev } \\
t \text {-value }\end{array}$ & $\begin{array}{l}0,0014 \\
0,0121 \\
0,3370\end{array}$ & $\begin{array}{l}0,0030 \\
0,0080 \\
0,6330\end{array}$ & $\begin{array}{l}0,0005 \\
0,0226 \\
0,1210\end{array}$ & $\begin{array}{l}0,0097 \\
0,0190 \\
1,7820 *\end{array}$ & \\
\hline return 13.30 & $\begin{array}{l}\text { Mean } \\
\text { Std Dev } \\
t \text {-value }\end{array}$ & $\begin{array}{r}-0,0067 \\
0,0128 \\
-1,4450 \\
\end{array}$ & $\begin{array}{r}-0,0057 \\
0,0108 \\
-1,0480 \\
\end{array}$ & $\begin{array}{r}-0,0029 \\
0,0116 \\
-0,6500 \\
\end{array}$ & $\begin{array}{l}0,0073 \\
0,0310 \\
1,4030 \\
\end{array}$ & \\
\hline return 14.00 & $\begin{array}{l}\text { Mean } \\
\text { Std Dev } \\
t \text {-value }\end{array}$ & $\begin{array}{r}-0,0020 \\
0,0141 \\
-0,5220 \\
\end{array}$ & $\begin{array}{l}0,0027 \\
0,0122 \\
0,6100 \\
\end{array}$ & $\begin{array}{r}-0,0023 \\
0,0096 \\
-0,5830 \\
\end{array}$ & $\begin{array}{r}-0,0008 \\
0,0245 \\
-0,1830 \\
\end{array}$ & $\begin{array}{r}-0,0045 \\
0,0196 \\
-0,9880 \\
\end{array}$ \\
\hline return 14.30 & $\begin{array}{l}\text { Mean } \\
\text { Std Dev } \\
t \text {-value }\end{array}$ & $\begin{array}{r}-0,0109 \\
0,0237 \\
-1,2920 \\
\end{array}$ & $\begin{array}{r}0,0000 \\
0,0202 \\
-0,0040 \\
\end{array}$ & $\begin{array}{r}-0,0052 \\
0,0139 \\
-0,6190 \\
\end{array}$ & $\begin{array}{l}0,0175 \\
0,0655 \\
2,0060 * *\end{array}$ & $\begin{array}{r}0,0000 \\
0,0080 \\
-0,0020 \\
\end{array}$ \\
\hline return 15.00 & $\begin{array}{l}\text { Mean } \\
\text { Std Dev } \\
t \text {-value }\end{array}$ & $\begin{array}{r}-0,0013 \\
0,0121 \\
-0,2080 \\
\end{array}$ & $\begin{array}{r}-0,0066 \\
0,0186 \\
-0,9790 \\
\end{array}$ & $\begin{array}{l}0,0070 \\
0,0270 \\
1,0450 \\
\end{array}$ & $\begin{array}{r}-0,0135 \\
0,0414 \\
-2,0100 * * \\
\end{array}$ & $\begin{array}{l}0,0033 \\
0,0146 \\
0,4730 \\
\end{array}$ \\
\hline return 15.30 & $\begin{array}{l}\text { Mean } \\
\text { Std Dev } \\
t \text {-value }\end{array}$ & $\begin{array}{l}0,0023 \\
0,0106 \\
0,3330 \\
\end{array}$ & $\begin{array}{r}-0,0001 \\
0,0274 \\
-0,0120 \\
\end{array}$ & $\begin{array}{r}-0,0022 \\
0,0249 \\
-0,3250 \\
\end{array}$ & $\begin{array}{l}0,0029 \\
0,0381 \\
0,4440 \\
\end{array}$ & $\begin{array}{r}-0,0028 \\
0,0215 \\
-0,3790 \\
\end{array}$ \\
\hline return 16.00 & $\begin{array}{l}\text { Mean } \\
\text { Std Dev } \\
t \text {-value }\end{array}$ & $\begin{array}{l}0,0060 \\
0,0297 \\
0,7230 \\
\end{array}$ & $\begin{array}{l}0,0117 \\
0,0334 \\
1,1870 \\
\end{array}$ & $\begin{array}{l}0,0165 \\
0,0203 \\
1,7860 *\end{array}$ & $\begin{array}{l}0,0276 \\
0,0584 \\
3,1750 \text { **** }\end{array}$ & $\begin{array}{l}0,0152 \\
0,0287 \\
1,6490 * \\
\end{array}$ \\
\hline
\end{tabular}

\section{Keterangan:}

* *signifikan pada level 10,00\%; **signifikan pada level 5,00\%; ***signifika n pa da level 1,00\%

* B, C dan D menunjukkan ukuran perusa haan yang di antara Portofo lio Terkecil dan Portofo lio Terbesar

\section{SIMPULAN, KEIERBATASAN PENEIIAN DAN SARAN}

\section{Simpulan}

Penelitian ini menguji retum yang terjadi untuk membuktikan validitas keberadaan day of the week dan Monday effect dengan menggunakan data intraday. Dua belas periode retum dibentuk untuk menjelaskan kedua fenomena ini. Terkecuali hari Jum'at dibentuk sepuluh periode karena periode 12.00 dan periode 13.30 dihilangkan. Hal ini disebabkan oleh perbedaan lamanya istirahat siang antar hari. Selanjutnya dilakukan pengujian dengan model regresi tanpa intersep yang hari sebagai varia bel ind ependen dengan metode dummy variabel, dan retum sebagai variabel dependennya. 
Hasil pengujian membuktikan bahwa keberadaan day of the week effect secara ril ada. Sebagai referensi atas hasil uji day of the weerk secara keselunuhan disajikan ringkasan dalam Tabel 7 yang merangkum hasil seluruh uji tersebut. Aka $n$ tetapi, hari yang berpengaruh terhadap retum tidak sama, atau dengan kata la in fenomena day of the week ini tidaklah konsisten harinya. Hari Senin, Selasa, Rabu, Kamis dan Jum'at secara bergantian mempengaruhi retum. Hasil ini relatif konsisten apabila dikendalikan dengan ukuran pensahaan, volume perdagangan, dan bentang tawa r-minta.

Selanjutnya dilakukan analisis terhadap Monday effect. Hipotesis Monday effect terdukung apabila retum pada har Senin adalah paling rendah dan signifikan terhadap retum. Hasil uji menunjukkan bahwa retum pada hari Senin dalam bandingannya dengan hari-hari yang lainnya tidak selalu terbukti memiliki retum negatif yang eksesif. Sela in itu, hari Senin tidak sela lu berpenga ruh terhadap retum. Hasil ini konsisten apabila portofolio dikendalikan dengan ukuiran perusahaan, volume perdagangan dan bentang tawar minta. Hal ini berarti fenomena Monday Effect hanya bersifat parsial saja. Keseluruhan hasil pengujian Monday effect tersaji pada Tabel 8.

Ta bel 7

Ringkasan Seluruh Hasil Uji Day of the Week

\begin{tabular}{|c|c|c|c|c|c|c|c|c|c|c|c|c|}
\hline \multirow{2}{*}{ Periode } & \multicolumn{12}{|c|}{ Retum } \\
\hline & 09.30 & 10.00 & 10.30 & 11.00 & 11.30 & 12.00 & 13.30 & 14.00 & 14.30 & 15.00 & 15.30 & 16.00 \\
\hline \multicolumn{13}{|c|}{ Panel: semua sampel } \\
\hline & + & + & + & + & + & $+H$ & $+1+$ & & + & & & $+1+$ \\
\hline \multicolumn{13}{|c|}{ Panel: ukuran perusahaan } \\
\hline Terkecil & & $+1+$ & ++ & & ++ & & +4 & & & & & $+1+$ \\
\hline B & + & + & & $+H$ & + & & + & & $+1+$ & $+1+$ & & + \\
\hline $\mathrm{C}$ & + & & ++ & & + & & $+H$ & & + & & & $+1+$ \\
\hline $\mathrm{D}$ & ++ & & & & + & & + & $+1+$ & + & & + & $+1+$ \\
\hline Terbesar & + & + & ++ & + & + & $+H$ & + & & + & & + & H \\
\hline \multicolumn{13}{|c|}{ Panel: volume perdagangan } \\
\hline Terkecil & & & & + & & & + & & 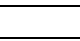 & ++ & & \\
\hline B & $+1+$ & & & + & $+H$ & + & + & & + & $+H$ & & + \\
\hline C & & & & & & & + & + & ++ & & & + \\
\hline $\mathrm{D}$ & + & $+1+$ & & & & & & ++ & & & & $+1+$ \\
\hline Terbesar & $+H$ & & & & $+1+$ & ++ & $+1+$ & & + & + & $+H$ & $+1+$ \\
\hline \multicolumn{13}{|c|}{ Panel: bentang tawar minta } \\
\hline Terkecil & + & + & + & & & ++ & $+1+$ & & ++ & & & $+1+$ \\
\hline $\mathrm{B}$ & ++ & & & & $+H$ & & & & & $+\mathrm{H}$ & & $+H$ \\
\hline C & $+1+$ & + & & & ++ & $+1+$ & & + & $+1+$ & ++ & & $+1+$ \\
\hline $\mathrm{D}$ & $+1+$ & + & & & $+\mathrm{H}$ & $+\mathrm{H}$ & $+H$ & + & & + & & $+1+$ \\
\hline Terbesar & + & ++ & $+1+$ & $+1+$ & & + & & & ++ & ++ & & $+1+$ \\
\hline
\end{tabular}

\section{Keterangan:}

Hipotesis day of the week terdukung lemah $(+)$; terdukung sedang $(++)$; terdukung kuat $(++)$ 
Tabel 8

Ringkasan Seluruh Hasil Uji Monday Effect

\begin{tabular}{|c|c|c|c|c|c|c|c|c|c|c|c|c|}
\hline \multirow{2}{*}{ Periode } & \multicolumn{12}{|c|}{ Retum } \\
\hline & 09.30 & 10.00 & 10.30 & 11.00 & 11.30 & 12.00 & 13.30 & 14.00 & 14.30 & 15.00 & 15.30 & 16.00 \\
\hline \multicolumn{13}{|c|}{ Panel: semua sampel } \\
\hline & + & & & & & & & & & & & $+1+$ \\
\hline \multicolumn{13}{|c|}{ Panel: ukuran perusahaan } \\
\hline Terkecil & & & & & & & & & & & & \\
\hline \multicolumn{13}{|l|}{ B } \\
\hline C & \# & & \# & & & & & & + & & & \\
\hline $\mathrm{D}$ & + & & & & & & & & & & & \\
\hline Terbesar & + & & & & & & & & + & & & \\
\hline \multicolumn{13}{|c|}{ Panel: volume perdagangan } \\
\hline \multicolumn{13}{|l|}{ Terkecil } \\
\hline \multirow{2}{*}{\multicolumn{13}{|c|}{$B$}} \\
\hline C & & & & & & & & + & \# & & & \\
\hline $\mathrm{D}$ & + & & & & & & & & & & & \\
\hline Terbesar & $+1+$ & & & & & & & & & + & & +1+ \\
\hline \multicolumn{13}{|c|}{ Panel: bentang tawar minta } \\
\hline Terkecil & & & + & & & & & & + & & & \\
\hline \multicolumn{13}{|l|}{ B } \\
\hline C & +11 & & & & & $+1+$ & & & & & & \\
\hline \multicolumn{13}{|l|}{ D } \\
\hline Terbesar & & + & & & & & & & & & & \\
\hline
\end{tabular}

Keterangan:

Hipotesis Monday effect terdukung lemah (+); terdukung sedang (++); terdukung kuat (+++)

\section{KETERBATASAN PENEIIAN DAN SARAN}

Penelitian ini masih dirasa kurang dalam pembuktian konsistensi day of the week dan Monday effect yang dikendalikan dalam basis-basis yang lain, seperti kondisi up-and-down market. Tipe pengendalian tersebut dapat digunakan untuk pembuktian konsistensi keberadaan dan pembuktian status kejadian day of the week dan Monday effect secara parsial serta insidentil selanjutnya. Demikian juga, terkait dengan sampel yang dipilih di dalam penelitian ini yang hanya menggunakan LQ45 belum mampu mencerminkan kondisi bursa di Indonesia secara komprehensif. Oleh karena itu, untuk tujuan pembuktian konsistensi keberadaan Monday effect yang secara komprehensif, maka penelitian selanjutnya dapat menggunakan seluruh populasi emiten.

Terkait dengan metode pengujian yang dipilih, yakni yang menggunakan model regresi tanpa intersep. Dengan model ini semua kategori dapat dimasukkan ke dalam model untuk menghindari adanya perfect multicollinearity. Akan tetapi, penggunaan model ini mengandung kelemahan dalam kaitannya dengan interpretasi nilai koefisien determinasi $\left(R^{2}\right)$. Nilai koefisien deteminasi yang dihasilka $n$ tidak dapat digunakan sebagai ukuran yang valid mengenai kemampuan model menjelaskan variabel dependen. Penelitian mendatang dapat menggunakan GARCH Method, karena metode ini lebih tepat untuk pengujian day of the week effect karena expected retum di bursa bersifat time varying dan mengandung conditional heteroskeda stic ity. 


\section{DAFTAR REFEENSI}

Abraham, A and Ikenbery, 1994, The Individual Investor and The Weekend Effect, J oumal of Fina ncial and Quantita tive Analysis, 19, 263-277.

Admati, A., and P. Pflederer, 1988, A Theory of Intraday Pattems: Volume and Price Variability, The Review of Financial Studies, Vol. 1 (1): 3-40.

Algifari, (1999). Pengaruh Hari Perdagangan terhadap Retum Saham di BEJ, Tesis UGM, Tidak Dipublika sikan.

Amihud, Y., and H. Mendelson, 1986, Asset Pricing and the Bid-Ask Spread, J oumal of Fina ncial Economic S, Vol. 17: 223-249.

Amihud, Y., and H. Mendelson, 1987, Trading Mechanism and Stock Retum: an Empinical Investigations, J oumal of Finance, Vol. 42: 533-53.

Amihud, Y., and H. Mendelson, 1991, Volatility, Effic iency and Trading: Evidence from the Japanese Stock Market, J oumal of Finance, Vol. 46: 369-89.

Angelidis and Lyroudi, 2003, Seasonalities in French Stock Market, 11 $11^{\text {th }}$ Annual Conference of the Multinational Finace Society, July 3-8, Constantinopel, Turkey.

Blume, L., D. Easley, and O'Hara, 1994, Market Statistic s and Technical Analysis: the Role of Volume, J oumal of Finance, 49(1): 153-181.

Cahyaningdyah, Dwi, 2004, Analisis Pengaruh Hari Perdagangan terhadap Retum Saham: Pengujian Week-Four Effect dan Rogalski Effect di Bursa Efek Jaka rta, Tesis UGM, Tidak Dipublika sikan.

Chan, H., and F. C. Nai, 1991, Structural and Retum Characteristics of Small and La rge Firms, J oumal of Fina nce, 46(4): 1467-1484.

Chan, K.C., W. G. Christie., and P. H. Schultz, 1995, Market Structure and the Intraday Pattem of Bid-Ask Sp reads for Nasdaq Securities, J oumal of Business, Vol. 68 (1): 35-60.

Cheung, Y. L., 1995, Intra day Retum and the Day End Effect: Evidence from the Hong Kong Equity Market, Joumal of Busines Finance and Accounting, Vol. 22 (7): 1023-1034.

Chriestie, J and Venables, P., 1973, Mood Changes in Relation to Age, TPI Score, Time, and Day, British J oumal of Social Science and Psychology, Vol.1, p. 67-79.

Cushing, David, and Madhavan, Ananth, 2000, Stock Retum and Trading at The Close, Notre Dame University Conference on Market Mic rostructure.

Cross, F., 1973, The Beha viour of Stock Price on Friday and Monday, Financial Analysis Joumal, Vol. 29 (6): 67-69.

Easley, D., and O'Hara, 1987, Price, Trade Ukuran perusahaan and Information in Sec urities Markets, J oumal of Fina ncia I Economics, 19: 69-90.

Fama, E. F., 1970, Efficient Capital Market: a Review of Theory and Empirical Work, J oumal of Finance, 25: 387-417.

Fama, E. F., 1991, Effic ient Ca pital Ma rkets II, J oumal of Fina nce, 46(51): 575-617.

Fama, E. F., and French, 1992, The Cross Section of Expected Retum, Joumal of Fina nce. 47: 427-465. 
French, K, 1980, Stock Retum and the Weekend Effect, Joumal of Financial Economics, Vol. 40: 31-62.

Gibbons, Michael R., and Hess, Patrick, 1981, Day of the Week Effect and Asset Retums, J oumal of Business, Vol. 54: 579-596.

Gomez, X.G., J. Hodoshima, and M. Kunimura, 1998, Does Ukuran perusahaan Really Matter in Japan? Association for Investment Management and Research. Nov./Dec : : 22-34.

Gujarati, Damodar N., 2003, Basic Econometrics, Fourth Edition, Boston: McGraw-Hill Companies, Inc.

Hartono, Jogiyanto M., 2003, Teori Portofolio dan Analisis Investasi, Edisi 3, J ogya karta: BPFE J ogyakarta.

Hartono, J ogiyanto M, 2005, Pasar Efisien Secara Keputusan, Jakarta: PT Gramedia Pustaka Utama.

Hartono, Tri, 2004, Pengaruh Perubahan Tick Ukuran perusahaan terhadap Kualitas Pa sar BEJ : Pengujian Intra da y Interval 30 Menit, Tesis UG M, Tidak Dipublika sikan.

Hamis, Lawrence, 1986, A Transaction Data Study of Weekly and Intra daily Pattems in Stock Retums, J oumal of Financial Ec onomics, Vol.: 8: 55-69.

Hamis, Lawrence, 1989, A Day-End Transa ctin Price Anomaly, Joumal of Fina ncial and Quantita tive Analysis, Vol.: 24: 29-45.

Haris, Lawrence and Gurel, E., 1986, Price and Volume Effects Associated with Changes in The S\&P 500 List: A New Evidence for The Existence of Price Pressure, J oumal of Finance, Vol.: 16 (September): 815-829.

Hess, A.C., and Frost, P.A., 1982, Tests for Price Effects of New Issues of Sea soned Sec urities, Joumal of Finance, Vol.: 36 (March): 11-25.

Ho, Y.K., 1990, Stock Retum Seasonalities in Asia Pacific Market, Joumal of Financial Management and Accounting, Vol.: 2(1): 47-77.

Ho, Y.K. and Cheung, Y.L., 1991, Behaviour of Intra-Daily Retum on Asian Emerging Market - Hongkong, Applied Economics, Vol.: 23(6): 957-966.

Huang, Y., S., D. Y. Liu, and T. W. Fu, 2000, Stock Price Beha viour over Trading and Non-Trading Periods: Evidence from the Taiwan Stock Exchange, Joumal Business and Fina ncial Accounting, Vol. 51: 575-602.

Karpoff, J.M, 1987, The Relation between Price Changes and Trading Volume: Survey, J oumal of Fina ncial and Qua ntita tive Analysis. 18: 109-126.

Kraus, A., and Stoll, H.R., 1972, Prices Impact of Block Trading on the New York Stock Exchange, J oumal of Finance, Vol.: 27(J une): 569-588.

Lakonishok and Levi, 1982, Weekend Effect on Stock Retum: A Note, Joumal of Finance, Vol. 37: 883-889.

Lakonishok, J. and E. Maberly, 1990, The Weekend Effect: Trading Pattems of Individual and Institusional Investors, J oumal of Fina nce, Vol. 45: 231-243.

Maberly, E., 1995, Eureka! Eureka! Discovery of the Weekend Effect Belongs to the Ancient Scribes, Fina ncial AnalysisJ oumal, Sept-Oct: 10-11.

Mc nish, T. H. and R. A. Wood, 1992, An Analysis of Intraday Pattems in Bid/Ask Spread for NYSE Sto cks, J oumal of Fina nce, 47(2): 753-764.

Mikkelson, W.H., and Partch, M.M., 1985, Stock Price Effects and Cost of Secondary Distributions, J oumal of Fina ncial Economics, Vol.: 14 (J une): 165-194. 
Miller, E.M., 1989, Explaining Intraday and Ovemight Price Behaviour, Joumal of Portfolio Management, Vol.: 15 (4): 10-16.

Mok, M.K., 1988, Opening and Quarter-Hour Intraday Sea sonalities in HongKong's Stock Market: Pre- and Post-Market Crash, Working Papers, No.: WP-88-06. Fa c ulty of Business Ad ministra tion, University of Hong Kong.

Rogalski, R. J., 1984, New Finding Regarding Day of the Week Retum over Trading and non Trading Periods: A Note, J oumal of Finance, Vol. 34 (5):1603-1614.

Rystom and Benson, 1989, Investor Pschology and the Day of the Week Effect, Fina ncial Ana lysts J oumal, Vol. 51.

Scholes, M.S., 1972, The Market for Securities: Substitution versus Price Pressure and The Effect of Information on Share Prices, J oumal of Business, Vol.: 45(April): 179211.

Sumiyana, 2007a, Monday Effect: Penalaran Logis Sebagai Akibat dari Pengaruh Psikologis, Pengaruh Periode Nonperdagangan, atau Pengaruh Kombinasian Keduanya (Studi Empinis Berbasis Data Intraday, Bursa Efek Jakarta 1999-2005), J umal Ekonomi dan Bisnis Indonesia, Vol.: 22 (2): 133-161.

Sumiyana, 2007b, Noise atau Kedatangan Informasi: Sebuah Phenomena Spesifik Perilaku Harga Saham di Pasar Modal Indonesia (Studi Empins Berbasis Data Intraday, Bursa Efek Jakarta 1999-2006), Jumal Ekonomi dan Bisnis Indonesia, Vol. 22 (3): 133-161.

Stoll, H. R., 1989, Inferring the Component of the Bid-Ask Spread: Theory and Empinical Test. J oumal of Finance. 44, 115-134.

Wang, L̇, and Erickson, 1997, A New Look at the Monday Effect, Joumal of Finance, Vol: 52 (5): 2171-2186.

Wood, R. A., T. H. Mc nish, and J . K. Ord, 1985, An Investigation of Transaction Data for NYSE Sto ck, J oumal of Finance, 40 (3): 739-741. 